United States Department of the Interior

Geological Survey

\title{
GEOLOGIC EVIDENCE FOR TRIGGERED SLIP ON THE CALAVERAS FAULT DURING THE MAGNITUDE 7.1 LOMA PRITTA EARTHQUAKE OF OCTOBER 17, 1989
}

$$
\text { by }
$$

\author{
P.H. McClellan ${ }^{1}$ and E.A. Hay ${ }^{2}$
}

OPEN-FILE REPORT

89-641

This report is preliminary and has not been edited or reviewed for conformity with U.S. Geological Survey editorial standards or with the North American Stratigraphic Code. Any use of trade, firm, or product names is for descriptive purposes only and does not imply endorsement by the U.S. Government.

1 U.S. Geological Survey, Menlo Park, CA

2 De Anza College, Cupertino, CA 


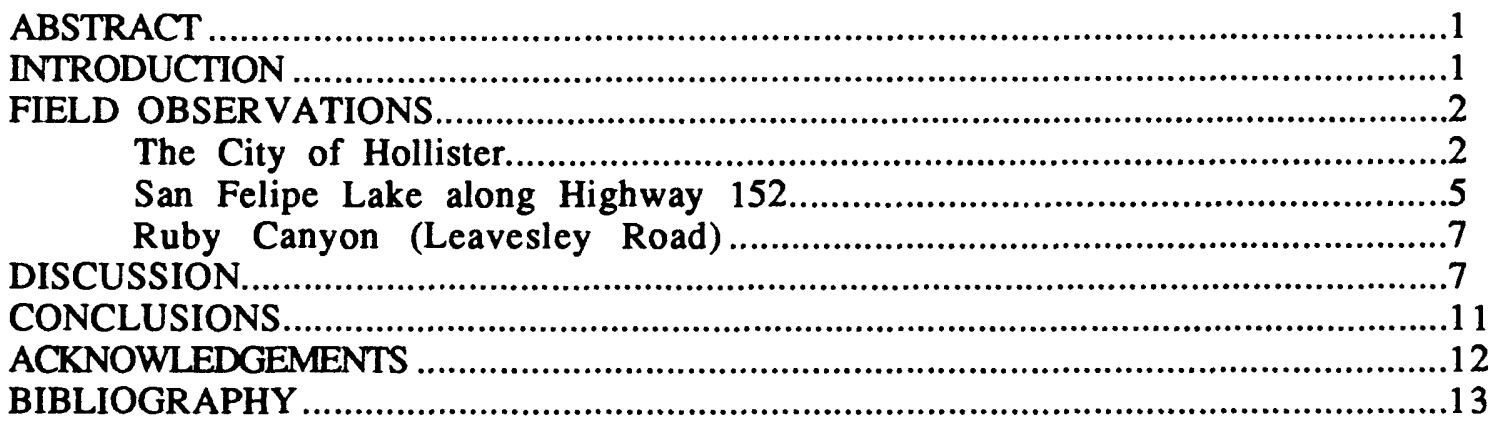

\section{ILLUSTRATIONS}

FIGURE 1. Map of coastal central California showing active faults, earthquake epicenters, and our study sites along the Calaveras fault.

FIGURE 2. Map of Hollister showing Calaveras fault traces and locations where we documented recent offsets after the Loma Prieta earthquake.

FIGURE 3. Buckled concrete sidewalk crossing fault at B Street in Hollister

FIGURE 4. Offset water-meter box and surrounding sidewalk crossing fault at B Street in Hollister.

FIGURE 5A. North-south sidewalk along Suiter Street longitudinally shortened along fault in Hollister.

FIGURE 5B. Different view of sidewalk in Fig. 5A.

FIGURE 6. En echelon shear cracks along fault crossing 5th street in Hollister.

FIGURE 7. Diagonally shattered concrete curb crossing fault at north edge of 5 th Street in Hollister.

FIGURE 8A. Close-up view of a transverse break in curb shown in Fig. 7, showing an adjacent soil crack possibly due to recent fault slip.

FIGURE 8B. Later view of soil area in Fig. 8A, showing soil crack has been erased by a trace of rainfall

FIGURE 9. Diagonal fracture in curb crossing fault at South Street..............26

FIGURE 10. Map of Highway 152 in vicinity of San Felipe Lake, $17 \mathrm{~km}$ northwest of Hollister, where crossed by Holocene traces of the Calaveras fault zone. 


\section{ILLUSTRATIONS (cont.)}

FIGURE 11. Right-lateral fault rupture across asphalt pavement of Highway 152

FIGURE 12. Recent en echelon cracks in roadbed at north side of Highway 152 .

FIGURE 13. Fresh soil crack in pasture along fault zone 10 meters north of asphalt fracture in Highway 152

FIGURE 14. Median stripes of Highway 152 north of San Felipe Lake, clearly showing right-lateral fault offset.

FIGURE 15. Border line of Highway 152 showing tension cracks parted by $5 \mathrm{~mm}$ right-laterally.

FIGURE 16. Sag pond within Calaveras fault zone north of Highway 152.

FIGURE 17. Older asphalt berm along Highway 152 displaced rightlaterally approximately $15 \mathrm{~mm}$

FIGURE 18. Map of Ruby Canyon vicinity along Calaveras fault southeast of Coyote Reservoir.

FIGURE 19. Seismicity map of the southern San Francisco Bay region showing $M 2$ and larger earthquakes from October 17 through October 20, 1989.

FIGURE 20. Seismicity map of the southern San Francisco Bay region showing M 4 and larger earthquakes during the 6 months prior to the Loma Prieta earthquake. 


\title{
GEOLOGIC EVIDENCE FOR TRIGGERED SLVP ON THI \\ CALAVERAS FAULT DURING TFE MAGNTUDE T. WOMA PRTA EARTHQUAKE OF OCTOBER 17, 1930
}

\author{
by
}

P.H. McClellan and E.A. Hay

\section{ABSTRACT}

After the magnitude (M) 7.1 Loma Prieta eartimquake on the San Andreas fault we surveyed selected sites along the Calaveras foult for evidence of recent surface displacement. In two areas along the Calaveras fault we documented recent right-lateral wiffets of maltural features by at least $5 \mathrm{~mm}$ within zones of recogniax historical acreep. The areas are in the city of Hollister and at Highway 152 mear San Felipe Lake, and are located approximately $25 \mathrm{~km}$ southeast 20 $\mathrm{km}$ northeast, respectively, of the nearest part of the rupture zone of the recent Loma Prieta earthquake. We constrain the times of the displacement events to within days or hours aif the Loma Prieta mainshock, and conclude that this earthquake om the San Amdreas fault probably triggered the $5 \mathrm{~mm}$ of observed stip on the Callaveras fault. This conclusion is corroborated by instrumental data from a nearby creepmeter station along the Calaveras fault.

\section{INTRODUCTION}

On October 17, 1989 at 17:04 (all dates anat times herain are Pacific Daylight Time) the M 7.1 Loma Prieta eartituguake occumed on the San Andreas fault in the southern Santa Cruz Mrountains. The fault segment that ruptured in this event included a part of the San Aradreas fault zone that previously had ruptured in $M$ 6-1/2 tio 7 earthquxikes in 1865 and possibly in 1838, and in the $M_{S}$, 3 San Francisco earthquake in 1906. The 1989 earthquake is the larger than M 5 to occur since 1906 on any part of the 1906 fault ibreak. Preliminary determinations of fault slip at depth in this event indicate an ofiqueslip mechanism with approximately 1.9 meters of right-lateral and 1.3 meters of reverse (up on southwest) components (Plafker and Galloway, 1989).

Previous earthquakes of M 6-1/2 to 7 on other faults in Celifornia are known to have triggered slip on neighborimg faults (Alikr, and others, 1972; Fuis, 1982; Sieh, 1982; Williams, and others, 1988; Sharp, 1989), and it is of interest to know whetizer the Loma Prieta earthquake also may have induced activity on neighboring faults. To explore this possibility, we conducted a reconnaiswance search for evidence of recent surface fault movement at selected sites alomg the 
Calaveras fault zone at approximately 68 and 92 hours after this recent earthquake.

The 110-km-long Calaveras fault zone branches to the eastern side of the San Andreas fault near latitude $36^{\circ} 40^{\prime} \mathrm{N}$, and thence strikes northwestward through the city of Hollister and through the foothills of the eastern San Francisco Bay area (Fig. 1). The Calaveras fault south of the Bay area historically has been creeping aseismically at a rate of approximately 0.5-1.3 cm/yr (Schulz, 1987), and links the creeping central segment of the San Andreas fault on the south with the creeping Hayward fault on the north along the base of the East Bay foothills.

Our search for triggered slip along the Calaveras fault zone focused on three areas: (1) the city of Hollister, approximately $25 \mathrm{~km}$ southeast of the rupture zone of the Loma Prieta earthquake, (2) the vicinity of San Felipe Lake, within approximately $20 \mathrm{~km}$ northeast of the rupture zone, and (3) Ruby Canyon, $4 \mathrm{~km}$ southeast of Coyote Reservoir, within about $18 \mathrm{~km}$ northeast of the rupture zone. We did not conduct a systematic search of all potentially moving traces of the fault zone due to insufficient time before a heavy rainfall, commencing on October 21, that began to erase or conceal the subtle evidence which we sought.

With the exception of Hollister, our interest was primarily in visiting research sites along the Calaveras fault that previously had been investigated by exploratory fault-trenching projects in which we have been involved. These investigations, conducted in 1983 under the National Earthquake Hazards Reduction Program, included 5 trenches at the San Felipe Lake site and 4 at Ruby Canyon (Cotton, and others, 1986).

\section{FIELD OBSERVATIONS}

\section{The City of Hollister}

In the city of Hollister the Calaveras fault consists of two traces, separated by $1 / 2$ to one $\mathrm{km}$, apparently only the western trace being active. Along the active trace west of the city center abundant evidence is visible in the old cultural features of the residential district to document historical surface creep along the fault (Rogers and Nason, 1971). North and south of the city the fault strikes N20-30W, but along most of its active trace through the residential district (between Nash Street on the south and 7th Street on the north) the fault strikes generally north-south (Fig. 2). Asphalt pavement crossing the fault here shows well-developed, left-stepping en echelon shear cracks, and east-west curbs show right-lateral offsets, some now as great as $50-60 \mathrm{~cm}$ in curbs constructed during the 1920's. Our observations 
here were confined to the residential blocks (mainly east-west streets) that cross the active trace.

After the Loma Prieta earthquake numerous examples of recent distress were evident in Hollister particularly in the curbs and sidewalks within the historically established zone of surface fault creep. Much of this seemingly recent distress may have resulted from slow fault movement prior to the Loma Prieta earthquake. However, two factors strongly suggest that the pavement damage we identified as "recent" was related to the earthquake: (1) the association of these sites with ubiquitous city maintenance barricades, yellow emergency flagging, underway pipeline repairs, and localized mud deposits from water that recently flowed from underground sources beneath the street at these sites - all effects of the recent earthquake; and (2) the presence of concrete rubble in the gutters at the sites of curb damage - which would have been removed by city maintenance crews during scheduled weekly street-sweeping (oral commun., Street Supervisor, City of Hollister, October 30, 1989) . In some cases, the recency of the pavement damage was established by additional evidence discussed below.

At B Street, between Powell and West Streets, well-developed old shear cracks step across the asphalt roadway along the fault. After the recent earthquake, damage was clearly evident at the south end of the asphalt shear zone where, along the sidewalk, two concrete slabs were compressed in an east-west direction into a upward tent-like buckle (Fig. 3). Across the street at the north end of the shear zone the asphalt surface was broken, possibly from a utility repair, and the hole recently in-filled with fresh sand and gravel. In the adjacent driveway and sidewalk recent cracks were apparent among the older ones, some lined with fragments of freshly broken concrete, and a concrete water-meter box centered in the sidewalk was bisected by a fracture and right-laterally offset (Fig. 4). Most, if not all, of this offset was probably the result of slow fault creep during the years preceding the October earthquake; however, the broken meter box and exposed meter within it, like many other earthquake damage sites in town, was blocked by a barricade.

Along the west side of Suiter Street (a north-south street) approximately one block north of A Street (Fig. 5A), the concrete curb and slabs in a 3-meter-long section of sidewalk were compressed in a north-south direction and underthrust a distance of at least one centimeter by an adjacent slab from the north (Fig. 5B). Suiter Street parallels the fault and lies within the creeping zone or along the western edge of it; although much of the observed deformation we describe may have developed within this zone during the years prior to the earthquake, how much is unknown to us. Nevertheless, pebblesized concrete fragments in the gutter where the curb had freshly 
spalled indicated that this barricaded sidewalk apparently was further damaged during the earthquake.

Where the fault crosses 5 th Street, between Powell and West Streets, pavement damage from decades of cumulative fault creep also is clearly evident in the well-developed, left-stepping shear cracks crossing the old roadway and the right-laterally offset sidewalk slabs (Fig. 6). During our visits barricades lined much of this block to the west of the fault where the north edge of the roadway had been excavated and back-filled during emergency water-line repairs following the earthquake. The clearest evidence of recent surface movement along the fault in Hollister was seen here where the north end of the zone of en echelon shears crossing the roadway meets a free-standing (not sidewalk-bordered) concrete curb. The 3- to 4-meter-long section of curb crossing the fault here appears relatively new (or recently resurfaced) compared to the adjacent curb sections to the east or west. At the time of our visit, this curb section was broken at two places which were approximately $1.5 \mathrm{~m}$ apart (Fig. 7). The western break was a single transverse fracture (strike north-south, dip vertical) offset right-laterally by approximately $2.5 \mathrm{~cm}$ (much of this displacement is probably due to prior aseismic creep). The eastern break was a more complex diagonal rupture (strike approximately $\mathrm{N} 45 \mathrm{E}$, dip SE) showing approximately $5 \mathrm{~mm}$ of right-lateral offset.

As explained below, the displacement evident in the fractured curb along 5th Street, at least in part, is associated closely in time with the October 17, 1989 Loma Prieta earthquake.

(1) At the time of our visit on October 20, 1989 an open crack (strike generally north-south) parted by 2 to $3 \mathrm{~mm}$ was visible in a plot of soil between the transverse fracture in the curb and the adjacent sidewalk (Fig. 8A). The ephemeral nature of this soil fracture is illustrated by the photograph in Figure $8 \mathrm{~B}$ (in which fracture is now erased) taken 24 hours after that in Figure 8A and following a "trace" (less than 0.01 inches) of rainfall (oral commun., representative of US National Weather Service, October 31,1989$)$. The last measurable rainfall in Hollister prior to October 20 was 0.34 inches on September 29, 1989, 18 days before the Loma Prieta earthquake. Thus, this soll crack was formed during the 21 days between September 29 and October 20.

(2) Freshly broken fragments of concrete up to $10 \mathrm{~cm}$ long had fallen or were in the process of spalling into the gutter from the diagonal break in this curb. According to the Hollister Department of Streets, Trees and Maintenance, this gutter is swept weekly on a Tuesday route (oral commun., representative of the City of Hollister, October 31, 1989). Thus, the curb was shattered after being last swept on Tuesday October 17 (at some 
time within the 12 hours preceding the Loma Prieta earthquake) and before the time of our first visit on Friday October 20.

Along South Street, between Powell and West Streets, approximately $10 \mathrm{~cm}$ of accumulated right-lateral shear is concentrated between two old sections of the south curb (also free-standing). Within one-half meter to the west of this old break, however, the curb is also broken by a fresh diagonal break (strike approximately N45E) very similar to that observed along 5th Street (noted above) and showing a right-lateral offset of approximately one cm (Fig. 9).

At the junction of Locust and Central Streets the fault strikes northwestward through the northwest corner of the intersection. At this corner was a curb and sidewalk freshly cracked with concrete rubble lying about the cracks, not unlike the concrete fractures described along B Street (above).

In the two above examples where curbs are cut by diagonal fractures (Figs. 7 and 9), a concrete slab abuts the left edge of the curb if the slab is viewed from the opposite side of the fault trace. This suggests that the recent, apparent right-lateral movement of the curbs may have been due in part or entirely to north-south hammering of the curbs by the adjoining slab during the earthquake shaking, rather than to tectonic right-slip. Alternatively, these diagonal fractures and the apparent lateral offset, like the buckled sidewalk noted along B Street, may have been in part or wholly the result of east-west compression, parallel to the curb line (normal to the Calaveras fault), during the ground shaking. The relationships between ground motions and some of these damaged engineering structures is not well understood at present.

\section{San Felipe Lake along Hiohway 152}

Fifteen $\mathrm{km}$ northwest of central Hollister the Calaveras fault passes along the western edge of San Felipe Lake and intersects State Highway 152 (Fig. 10). For the northernmost $9 \mathrm{~km}$ of this distance the fault is a single trace that strikes N2OW. Immediately north of Highway 152 it enters the foothills of the Diablo Range where it abruptly bends 5-10 degrees more westerly, and becomes a broad zone encompassing at least six Holocene traces, four of which show historical creep where they offset fence lines (Armstrong, and others, 1980).

During the M 5.9 Coyote Lake earthquake on August 6, 1979 (Fig. 1) tectonic slip on the Calaveras fault ruptured the highway here. Cotton and others (1979) note that 6 hours after this earthquake, "just east of BM 160, a very well-defined crack crosses the highway and extends beyond the pavement; the crack strikes N2OW and displays 2 to 3 millimeters of right-lateral displacement." One day after the $\mathbf{M}$ 
6.2 Morgan Hill earthquake of April 24, 1984 (Fig. 1), a fresh crack "offset about $1 \mathrm{~cm}$ right-laterally" also was observed to cut the asphalt here and was attributed to slip during this earthquake (Galehouse and Brown, 1987). This asphalt break could be traced into hairline cracks in the adjacent soil north and south of the highway, and with them formed a zone that trended N18W (ibid.). A second assessment of the rupture here 3 days after the Morgan Hill earthquake (Harms, and others, 1987) identified cracks opened by only $1 \mathrm{~mm}$ at the north side of the road as the principal evidence of local fault slip in this earthquake; these had an approximate strike of N34W and a displacement vector of N52W (ibid., Table 6.1). (We do not understand the reason for this disagreement in crack orientation and slip magnitude after the Morgan Hill earthquake, unless possibly different sets of cracks along the highway are being described above, or perhaps the later observers regarded much of the " $1 \mathrm{~cm}$ " of asphalt displacement to be older than this earthquake.)

After the Loma Prieta earthquake we observed a single continuous crack extending entirely across the asphalt of Highway 152 and into the gravel fill of the roadbed on the north and south sides of the highway (Fig. 11). The pavement rupture was located about 65 meters east of BM 160. In the fill at the north edge of the highway at least three left-stepping en echelon cracks were visible that were parted by up to $5 \mathrm{~mm}$ (Fig. 12); additional soil cracks were visible 10 meters north of the highway in a pasture where the strike of the highway shear zone projected across the compacted tire tracks of a dirt road (Fig. 13). The fracture in the asphalt and those in the adjacent fill formed a zone trending approximately N17W. However, where this fracture crossed painted highway stripes right-lateral offset was clearly evident (Fig.14) and extension across the fracture indicated shear in a direction of approximately N61W (Fig.15). These crack and displacement orientations are not unlike those observed here after the moderate earthquakes in 1979 and 1984. At the time of our visit at 11:00 on October 21, 1989 (90 hours after the Loma Prieta earthquake) $5 \mathrm{~mm}$ of right-lateral highway offset was measured parallel to this shear direction.

Along the north edge of the highway approximately 100 meters to the east of the throughgoing fracture noted above are two smaller arcuate cracks that extend 1 to 2 meters across the pavement of the westbound lane. This pair of small cracks and the principal throughgoing fracture to the west coincide approximately with the east and west boundaries, respectively, of a closed depression (sag pond) north of and crossed by the highway (Fig. 16).

The pavement fractures described above cut a layer of asphalt that covers an older road surface. Weathered cracks that remain exposed in the older road surface are coincident with the fresh cracks in the recent asphalt and indicate that distress has repeatedly occurred 
at these locations, probably from aseismic creep and possibly in association with previous earthquakes. At the location of the principal fracture noted above, at least $15 \mathrm{~mm}$ of total slip is recorded in the older road surface (Fig. 17).

The recency of the fractures and shear cracks in the newer highway pavement can be constrained within a few months to a few weeks. According to the paving contractor for the State Department of Transportation, this section of Highway 152 was resurfaced with asphalt between April 7 and 10, 1989 (oral commun., Mr. Oscar Reyes, Ashley Construction Co., October 25, 1989). Thus, at the time of our visit the asphalt pavement and any fractures that may have broken it were no older than 27 weeks. With regard to the soil cracks, especially those north of the throughgoing highway fracture that cross the silt and clay road surface in the nearby pasture, these were most probably formed after the last significant rainfall in this area which, as noted above, was on September 29, 1989.

\section{Rubr Canyon (Leavesley Road)}

Leavesley Road crosses the Calaveras fault $8.5 \mathrm{~km}$ northwest of San Felipe Lake, $0.8 \mathrm{~km}$ inside the mouth of Ruby Canyon (Fig. 18). Here a zone of established en echelon shear cracks clearly marks the path of the fault across the old asphalt roadway. On October 21 , no fresh parting or evidence of recent propagation of the shear cracks was apparent. However, in the absence of young cultural features athwart the fault trace here, recent displacements would be difficult to discern, especially if they were on the order of a few $\mathrm{mm}$.

Eight-tenths of a kilometer to the northwest, also where this road crosses the fault, old shear cracks are again well developed. In some old cracks the mud filling was noticeably parted by 1 to $2 \mathrm{~mm}$. However, this slight crack width may reasonably be attributed to 1 to 2 months of slow creep and/or desiccation shrinkage of the fine-grained sediment, rather than to recent sudden slip.

\section{DISCUSSION}

At the time of our survey, recent and significant ground movements were evident along the trace of the Calaveras fault in the city of Hollister and across Highway 152. However, to assess the tectonic significance of these ground ruptures several questions (some interrelated) must be answered:

(1) Were the movements, although apparently recent, the result of slow aseismic fault slip such as has historically been accumulating along the fault? 
(2) Were they sudden or otherwise of short duration?

(3) Were they related in time to the Loma Prieta earthquake?

(4) Were they due to coseismic slip related to earthquakes on the Calaveras fault?

(5) Were they the result of an afterslip (delayed creep) event related to significant earthquakes on the Calaveras fault during the months preceding our observations?

(6) Were they due to right-lateral tectonic shear along the fault or to intense and chaotic surficial ground motions during the earthquake shaking?

Questions (1), (2) and (3) may be answered as follows. At Highway 152 the age of the pavement limits the age of the observed asphalt fractures to less than six months. The average historical rate of aseismic creep along the fault zone here is not well know but, based on that at Shore Road $5 \mathrm{~km}$ to the southeast (Schulz, 1987), is probably on the order of one $\mathrm{cm}$ per year. Hence, the $5 \mathrm{~mm}$ right-lateral displacement measured across tension cracks in this asphalt pavement is consistent with that expected over 6 months from aseismic creep. However, several considerations cast some doubt on this explanation.

First, rupturing of asphalt pavement by slow right-lateral shear typically assumes the form of left-stepping en echelon fractures, as are visible on most other roadways crossing the Calaveras and other creeping faults in central California (e.g., Galehouse and Brown, 1987; Schulz, 1987). The continuous, single right-lateral fracture observed breaking the surface of Highway 152 distinctly differs from the zone of arcuate or sigmoidal fissures typical of creep-rupture in asphalt, and more resembles brittle fracture as would probably result from sudden fault slip. This may be insignificant, however, if beneath the new asphalt the older pavement beyond our inspection is constructed in sections. The colinearity of the asphalt crack (as was also described here after the Coyote Lake earthquake; Cotton and others, 1979) may simply reflect a linear seam between laterally-offset slabs of older pavement.

Second, it is likely that a fresh layer of asphalt under gradual shear or tension initially would behave ductilly to some extent before crack failure. Hence, a portion of the creep that accumulated during the 6 months preceding the October earthquake probably is not reflected in the parting of the highway asphalt, and the measured $5 \mathrm{~mm}$ of displacement probably exceeds that due to aseismic creep alone. 
Third, the soil cracks north of the highway must have developed within the short period of 21 days prior to our visit on October 20, after the last significant previous rainfall. Assuming the average creep rate noted above, the amount of slip accumulated during this threeweek interval would account for only one-half $\mathrm{mm}$ of crack width in contrast to the parting of up to $5 \mathrm{~mm}$ observed in these cracks.

In Hollister the curbs crossing the Calaveras fault have been severely distorted by continual right-lateral shear that has occurred aseismically over the past several decades. It is therefore possible that cumulative aseismic slip rather a recent and sudden significant slip event is responsible for the freshly broken curbs and soil cracks such as those on 5th Street. This too is considered very unlikely, however. The average creep rate in Hollister is 9 to $13 \mathrm{~mm} / \mathrm{yr}$ (Schulz, 1987). The time interval over which the observed displacements here could have occurred is constrained by the rainfall and city maintenance records to be less than 21 days and probably less than 12 hours. The expected displacements accrued from aseismic slip during these short periods range from about $0.7 \mathrm{~mm}$ to negligible, again far less than the several $\mathrm{mm}$ observed.

The displacements we observed are consistent with right-lateral slip on the Calaveras fault. The convergence of time constraints suggests that the observed recent offsets in Hollister developed during a brief interval, if not an instant, between the times of less than 12 hours before the Loma Prieta earthquake to less than 68 hours afterward. Similarly, the apparently sudden rupture of the fault trace north of Hollister near Highway 152 during the 21 rain-free days noted above, likewise associates the time of origin of these fractures to near the time of the October 17 earthquake. We believe it is most likely that these observed displacements represent a single episode of movement along the southern Calaveras fault that was simultaneous with or immediately followed the Loma Prieta earthquake and, hence, was probably triggered by dynamic strain during this shock. On the basis of geologic evidence, we cannot rule out movement of the Calaveras fault in the hours before the Loma Prieta earthquake, however.

It is possible that the displacements we observed resulted from coseismic slip during earthquakes on the Calaveras fault around the time of the Loma Prieta earthquake (Question 4). A plot of seismicity from the time of the earthquake on October 17 through October 20 (Fig. 19), however, reveals only one earthquake on the southern section of the Calaveras fault. This event, of M 2.2 on October 20, 1989 , about $15 \mathrm{~km}$ northeast of San Felipe Lake and $1.7 \mathrm{~km}$ deep (Lynn Dietz, USGS, unpublished data), we regard to be too small and too distant from our sites to be significant. Likewise, no earthquakes larger than M 3.0 occurred along the Calaveras fault during the 21 rain-free days ending with the time of our observations (ibid.), which 
fails to support this explanation for the observed displacements. It is further possible that the displacements we describe include a coseismic strain step caused by the August 8, 1989 Lake Elsman earthquake (M 5.2) on the San Andreas fault, also in the Loma Prieta rupture zone. Nevertheless, we believe that a strain step, if any, that may have occurred on the Calaveras fault from this relatively small earthquake would be a small fraction of the $5 \mathrm{~mm}$ we observed.

The Calaveras fault is known to be sensitive to changes in regional strain and stress (Schulz, 1987), based in part on observations of accelerated creep, or afterslip, that has been triggered by prior moderate earthquakes along this fault. In the hours to weeks following the M5.9 Coyote Lake earthquake in 1979 and M6.2 Morgan Hill earthquake in 1984 (both on the Calaveras fault north of San Felipe Lake), several afterslip events were recorded at the the USGS Shore Road creepmeter (ibid.) located along the Calaveras fault $5 \mathrm{~km}$ southeast of San Felipe Lake. With regard to Question 5 above, it is possible that the displacements observed at San Felipe Lake were due to afterslip, during the 21 rain-free days, that was triggered by an earlier earthquake on the Calaveras fault. If so, a moderate magnitude earthquake nearby on the Calaveras fault should be evident in the record of seismicity during the hours to weeks before our observations. The most recent prior earthquake of a significant size on this fault was a M 5.2 event near Calaveras Reservoir, $60 \mathrm{~km}$ northeast of San Felipe Lake, on April 3, 1989 (Lynn Dietz, USGS, unpublished data), 6 months before our survey. Although it was of moderate magnitude, we believe this earthquake was too remote in time and space to cause afterslip of the amount and in the locations of the offsets we observed. After April 3 there were no Calaveras earthquakes of M 4 or larger before the Loma Prieta shock, and smaller earthquakes are not likely to cause significant surface fault rupture.

Hence, the fault movement we document appears to represent accelerated creep independent of prior earthquakes on the Calaveras fault. The timing of this episode of accelerated creep, moreover, strongly suggests that it represents slip on the Calaveras fault induced by dynamic crustal strain associated with the M 7.1 Loma Prieta earthquake.

In answer to Question 6, some of the displacements in the residential neighborhoods of Hollister, as our observations indicate, alternatively may be explained by processes other than right-lateral fault slip. Among the alternatives is the interaction of artificial (engineering) structures with each other and with the earth materials beneath them during the intense and chaotic surficial ground motions in the Loma Prieta earthquake. The right-lateral displacement of Highway 152, however, is clearly consistent with right-slip of a tectonic origin on the underlying Calaveras fault. It closely resembles 
in style, magnitude and location the right-lateral surface ruptures observed here after the earlier M 5.9 Coyote Lake earthquake (Cotton, and others, 1979) and the M 6.2 Morgan Hill earthquake (Galehouse and Brown, 1987) on the Calaveras fault.

On balance, the geologic evidence favors tectonic right-slip of up to $5 \mathrm{~mm}$ at the ground surface along the Calaveras fault near the time of the Loma Prieta earthquake. Instrumental support for this conclusion is provided by creepmeter telemetry data from the USGS Shore Road station, located along the fault between Hollister and San Felipe Lake (S. Schulz-Burford, unpublished data). These data record a right-lateral strain step of $4.98 \mathrm{~mm}$ from a slip event along the Calaveras fault on October 17, 1989, during the 10-minute interval from 17:00 and 17:10 - almost certainly fault-slip triggered by the Loma Prieta earthquake at 17:04.

\section{CONCLUSIONS}

The Calaveras fault at San Felipe Lake and probably also at Hollister experienced slip of up to $5 \mathrm{~mm}$ at the ground surface near the time of the M7.1 Loma Prieta earthquake on October 17, 1989. This slip event apparently is neither coseismic with nor afterslip from an earthquake on the Calaveras fault. We infer that this event most likely was triggered by dynamic strain (ground shaking) resulting from the Loma Prieta earthquake on the nearby San Andreas fault. Our observations and the supporting USGS creepmeter data collectively document triggered surface rupture of the Calaveras fault along a zone at least $17 \mathrm{~km}$ in length. Hence, like some active faults in southern California, the Calaveras fault and, we speculate, perhaps other creeping faults in the San Francisco Bay region, are subject to triggered aseismic slip from large off-fault earthquakes. 


\section{ACKNOWLEDGEMENTS}

We thank Christopher DiLeonardo and Sandra Schulz-Burford for their reviews of an early draft of this report, and we are grateful to Sandra Schulz-Burford, Lynn Dietz and David Oppenheimer for providing us with unpublished USGS creepmeter and seismicity data. We also thank representatives of the City of Hollister, the California Department of Transportation, and the National Weather Service for providing us with information critical to documenting our observations. 


\section{BIBUIOGRAPHY}

Allen, C.R., Wyss, M., and others, 1972, Displacements on the Imperial, Superstition Hills, and San Andreas faults triggered by the Borrego Mountain Earthquake: in The Borrego Mountain earthquake of April 9, 1968, US Geological Survey Bulletin 787:87104.

Armstrong, C.F., Wagner, D.L., and Bortugno, E.J., 1980, Movement along the southern Calaveras fault zone as shown by fence line surveys: in Streitz, R., and Sherburne, R., eds., 1980, Studies of the San Andreas fault zone in northern California: Calif. Division of Mines and Geology, Special Report 140:29-40.

Cotton, W.R., Cochrane, D.A., and Coyle, J.M., 1979, Preliminary field notes of the ground surface effects associated with the August 6, 1979, Coyote Lake earthquake: Consultants report prepared by William Cotton and Associates, $10 \mathrm{p}$.

Cotton, W.R., Hall, N.T., and Hay, E.A., 1986, Holocene behavior of the Hayward-Calaveras fault system, San Francisco Bay Area, California: Final Tech. Rept. for USGS Contract No. 14-08-0001-20555, 15 pp., 4 plates.

Fuis, G.S., 1982, Displacement on the Superstition Hills fault triggered by the earthquake: in The Imperial Valley, California, earthquake of October 15, 1979, US Geological Survey Professional Paper 1254:145-154.

Galehouse, J.S., and Brown, B.D., 1987, Surface displacement near Hollister, California: in Hoose, S.N., ed., 1987, The Morgan Hill, California, earthquake of April 24, 1984, US Geological Survey Bulletin 1639:69-72.

Harms, K.K., Clark, M.M., and others, 1987, The search for surface faulting: in Hoose, S.N., ed., 1987, The Morgan Hill, California, earthquake of April 24, 1984, US Geological Survey Bulletin 1639:61-68.

Harsh, P.W., and Burford, R.O., 1982, Alignment-array measurements of fault slip in the eastern San Francisco Bay Area, California: in Hart, E.W., Hirschfeld, S.E., and Schulz, S.S., eds., 1982, Proceedings, Conference on Earthquake Hazards in the Eastern San Francisco Bay Area, Calif. Dept. of Conservation, Division of Mines and Geology, Special Publication 62:251-260.

Hoose, S.N., ed., 1987, The Morgan Hill, California, earthquake of April 24, 1984, US Geological Survey Bulletin 1639, 256 p. 1 plate. 
Plafker, G., and Galloway, J.P., ed., 1989, Lessons learned from the Loma Prieta, California, earthquake of October 17, 1989, US Geological Survey Circular 1045, 48 p.

Radbruch-Hall, D.H., 1974, Map showing recently active breaks along the Hayward fault zone and the southern part of the Calaveras fault zone, California: US Geological Survey Misc. Inv. Series Map I-813, scale $1: 24,000$.

Rogers, T.H., and Nason, R.D., 1971, Active displacement on the Calaveras fault zone at Hollister, California: Seism. Soc. America Bulletin 61:399-416.

Schulz, S.S., 1987, Response of U.S. Geological Survey creepmeters near Hollister, California: in Hoose, S.N., ed., 1987, The Morgan Hill, California, earthquake of April 24, 1984, US Geological Survey Bulletin 1639:111-115.

Sharp, R.V., 1989, Pre-earthquake displacement and triggered displacement on the Imperial fault associated with the Superstition Hills earthquake of 24 November 1987: Seism. Soc. America Bulletin 79:466-479.

Sieh, K.E., 1982, Slip along the San Andreas fault associated with the earthquake: in The Imperial Valley, California, earthquake of October 15, 1979, US Geological Survey Professional Paper 1254:155-159.

Williams, P:L., McGill, S.F., and others, 1988, Triggered slip along the San Andreas fault after the 8 July 1986 North Palm Springs earthquake: Seism. Soc. America Bulletin 78:1112-1122. 
FIGURES

15 


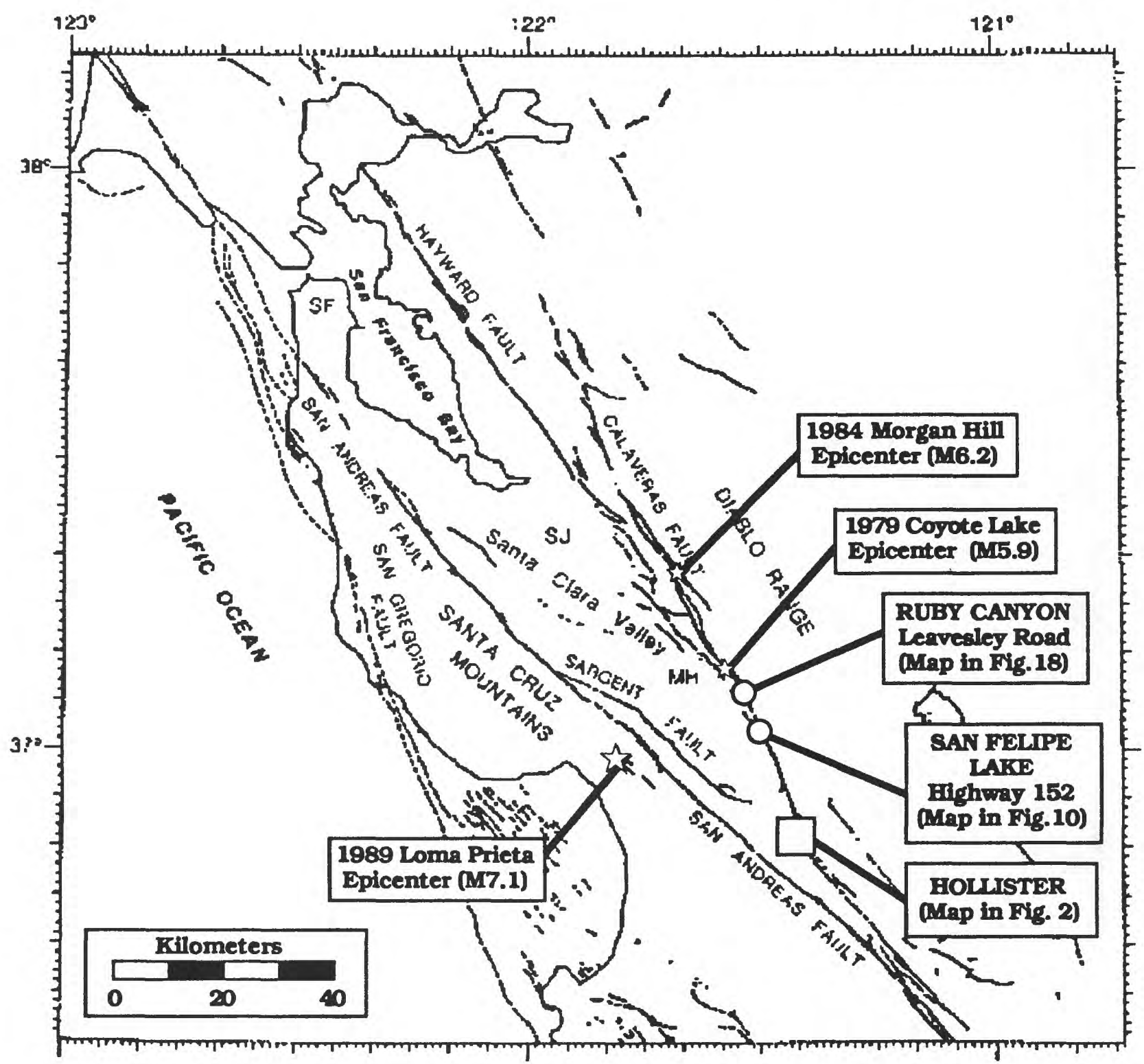

FIGURE 1. Location map of coastal central California showing active faults, epicenters of recent moderate to large earthquakes, and three sites along the Calaveras fault we investigated for evidence of surface displacement triggered by the Loma Prieta earthquake of October 17. 1989. (Modified from Hoose, 1987.) 


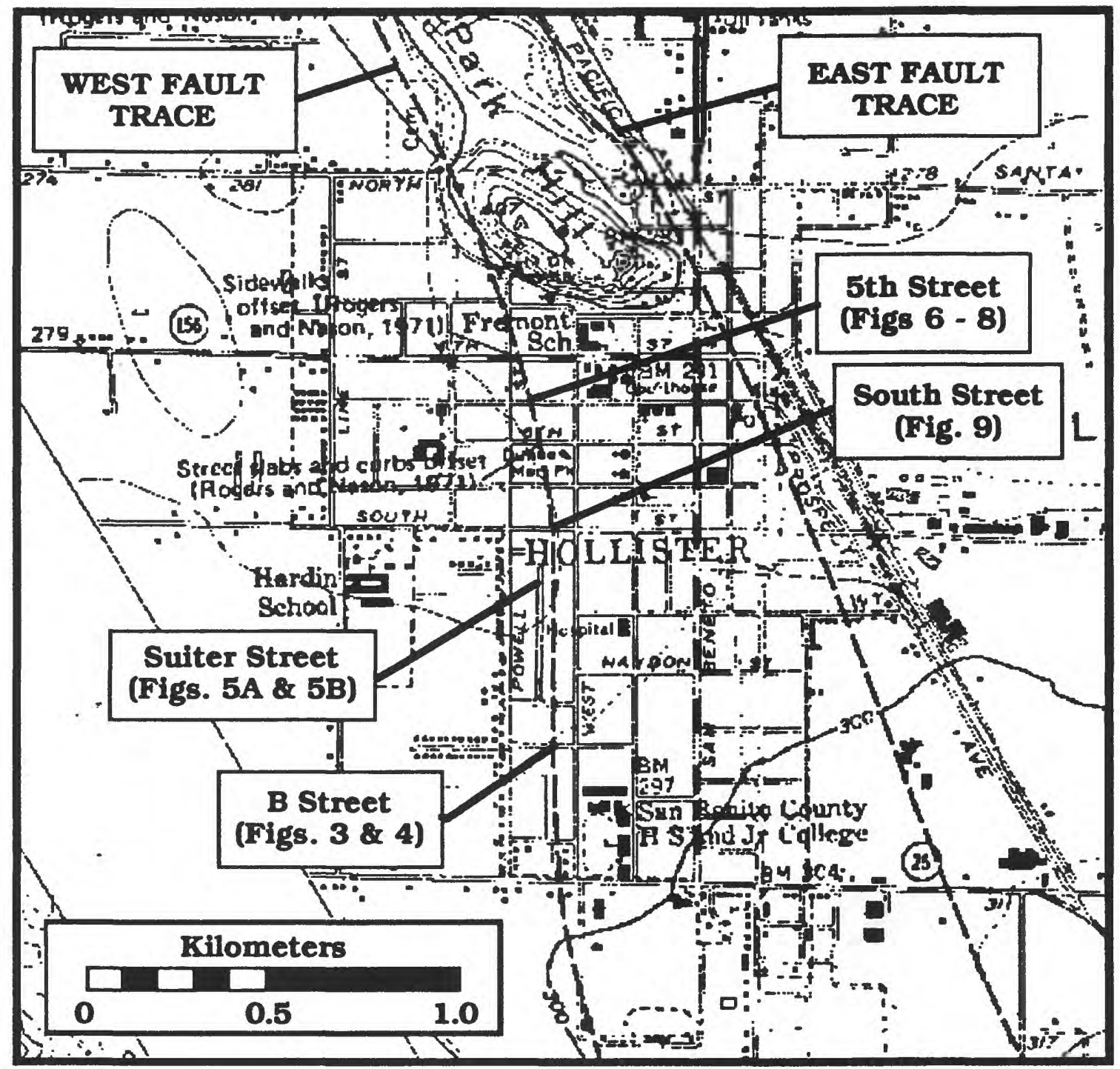

FIGURE 2. Map of Hollister showing Calaveras fault traces and locations where we photo-documented recent displacement of cultural features after the Loma Prieta earthquake. 


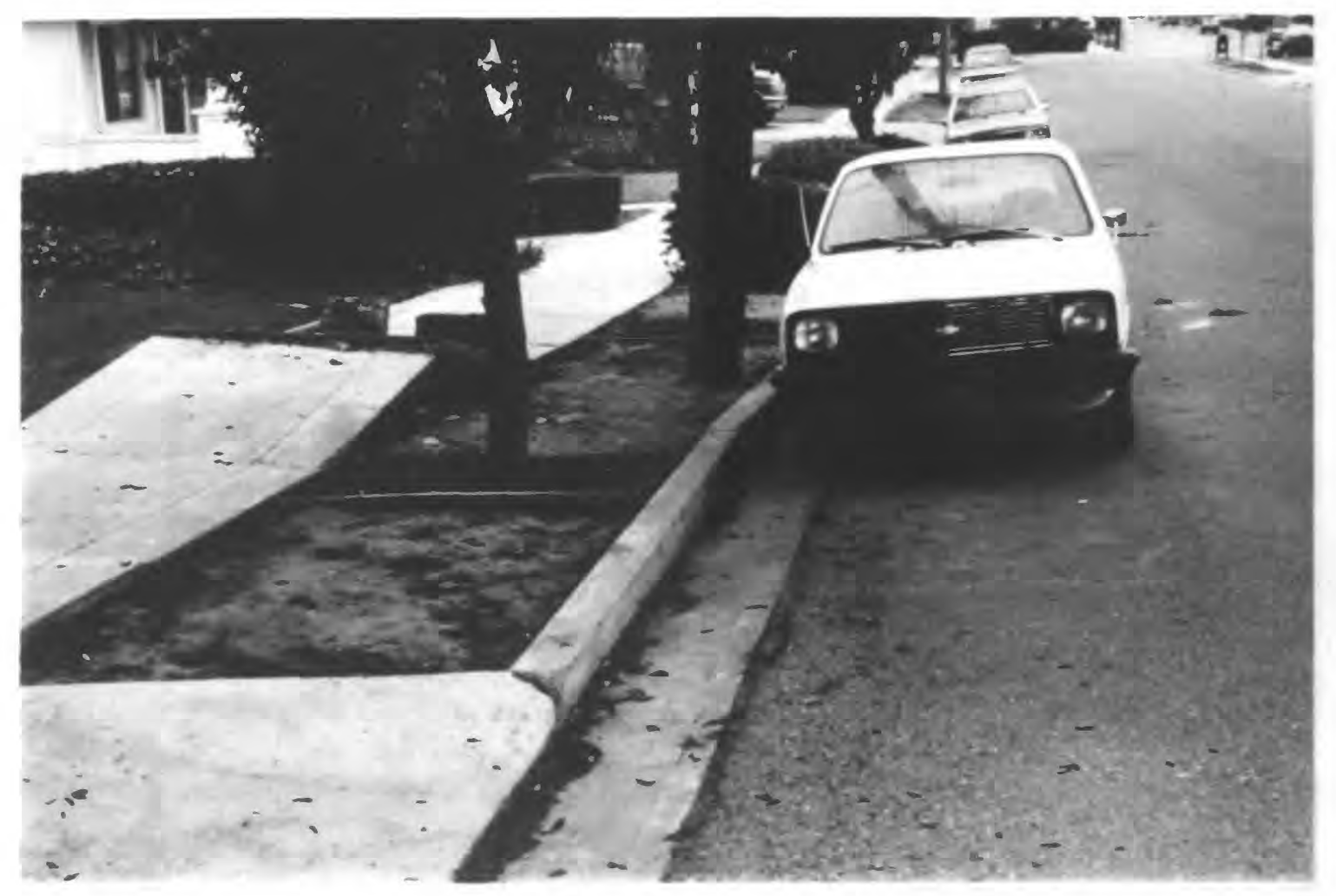

FIGURE 3. View toward west of buckled concrete pavement at south side of B Street, between Powell and West Streets, where Calaveras fault intersects sidewalk in Hollister. 


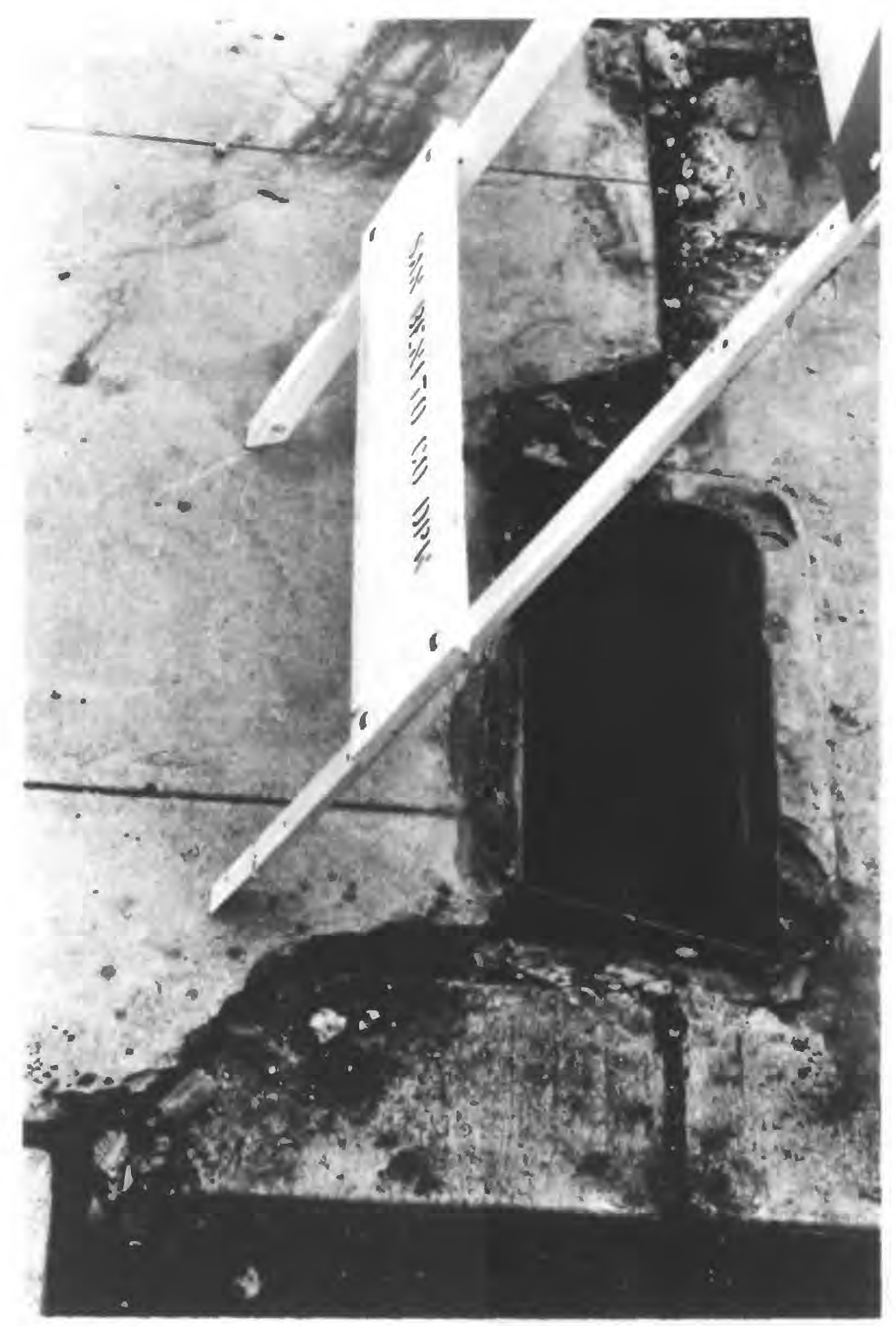

FIGURE 4. Right-laterally faulted concrete water-meter box and surrounding sidewalk at north side of B Street in Hollister (north is toward bottom of picture) where sidewalk intersects Calaveras fault. 


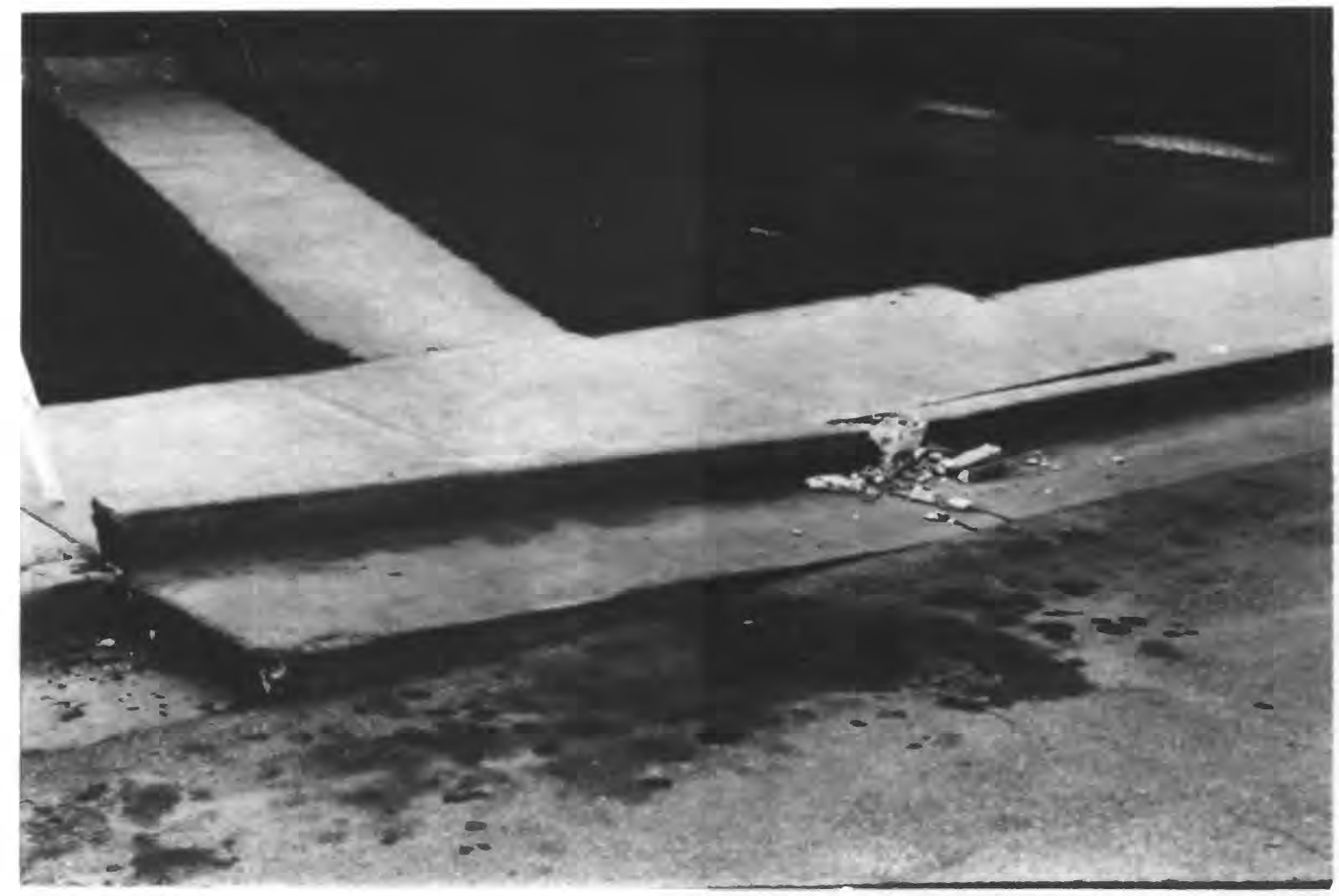

FIGURE 5A. North-south concrete sidewalk in Hollister along west side of Suiter Street, longitudinally shortened apparently by movement along the Calaveras fault zone. 


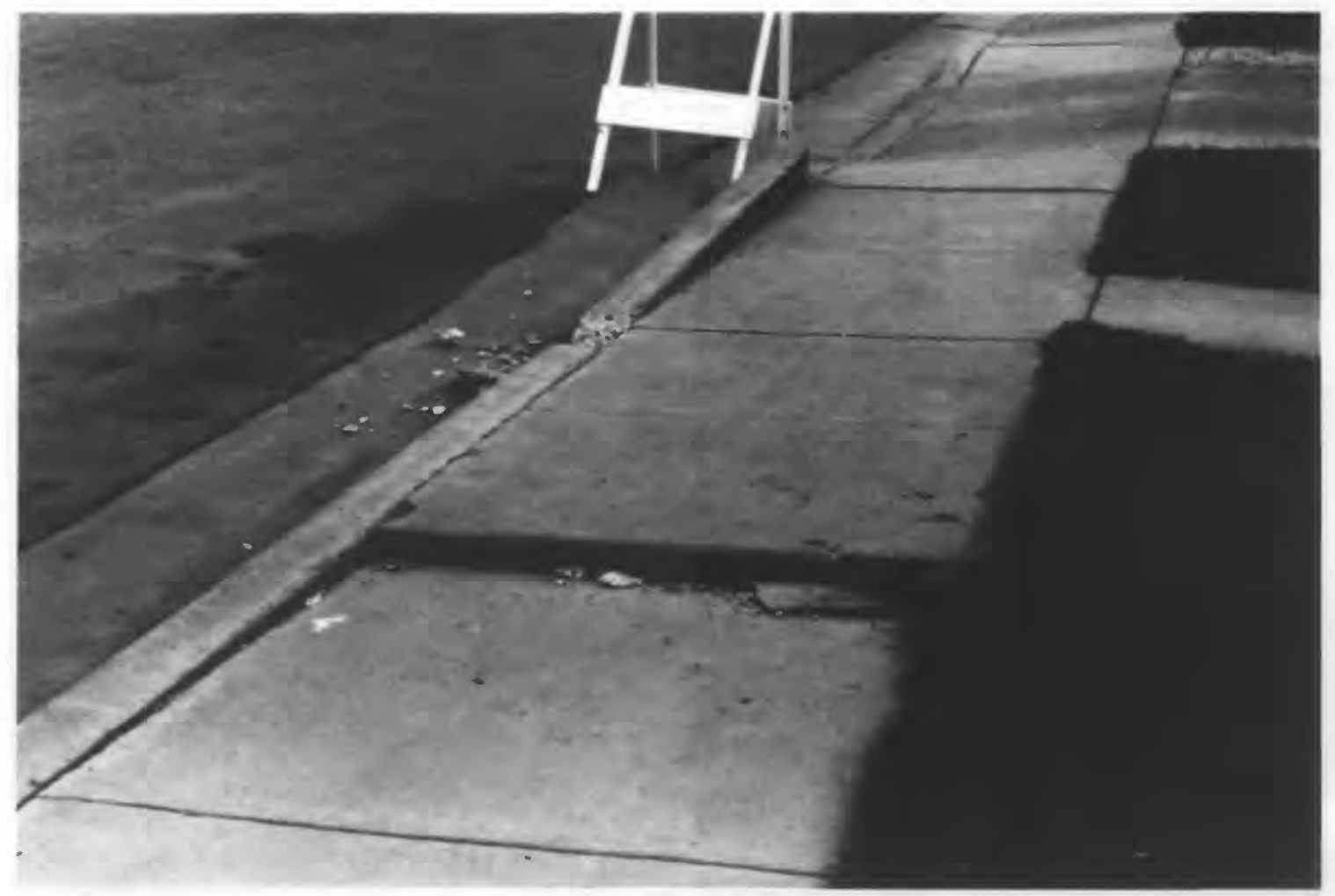

FIGURE 5B. View toward south of sidewalk in Fig. 5A. Note shortening of sidewalk indicated by overthrusting of far concrete slab toward viewer. 


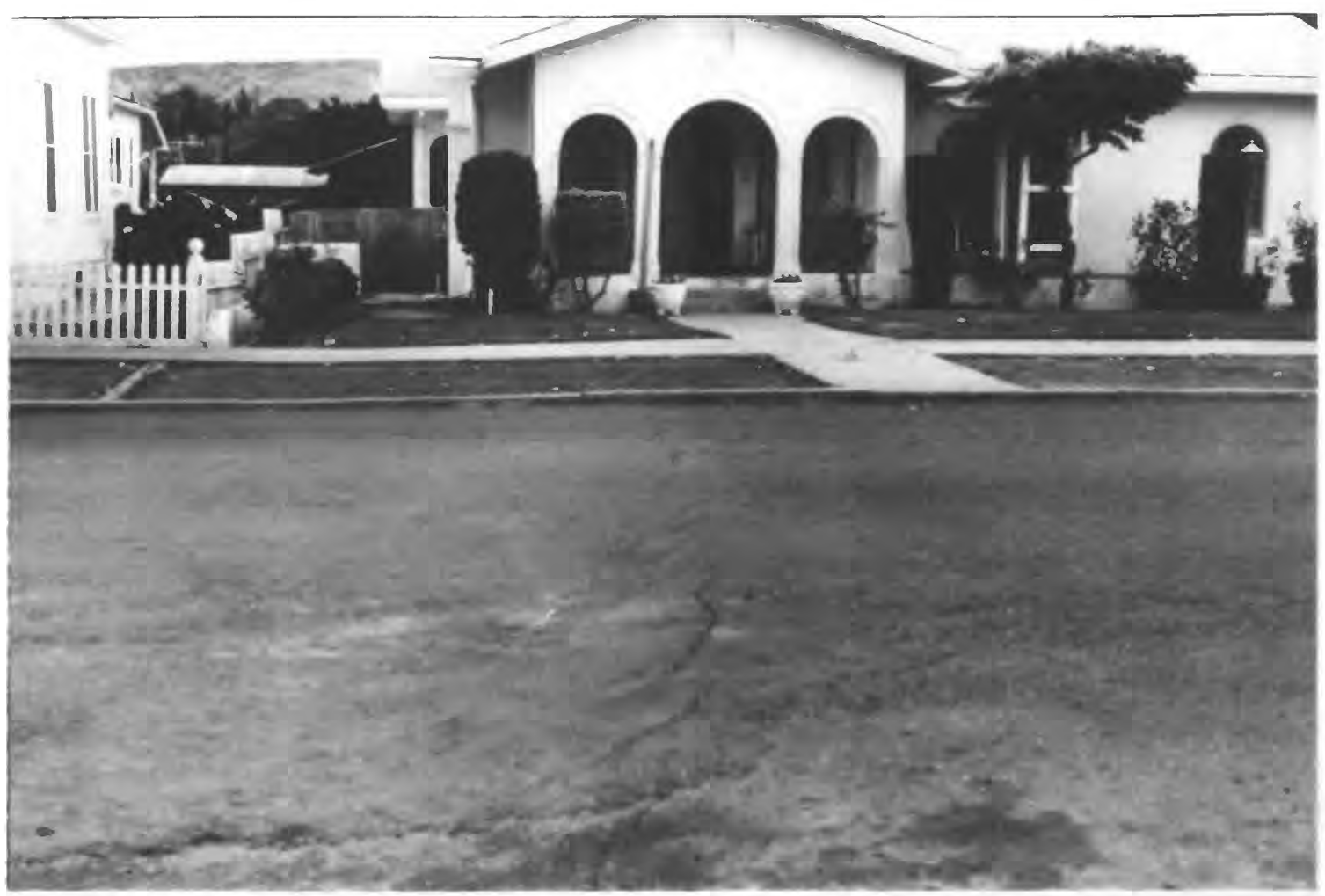

FIGURE 6. View northward along active western trace of Calaveras fault zone at 5th Street, between Powell and West Streets in Hollister. Note en echelon shear cracks in asphalt pavement, and breaks in the free-standing concrete curb at far edge of street (close-up views in Figs. 7 and 8 ). 


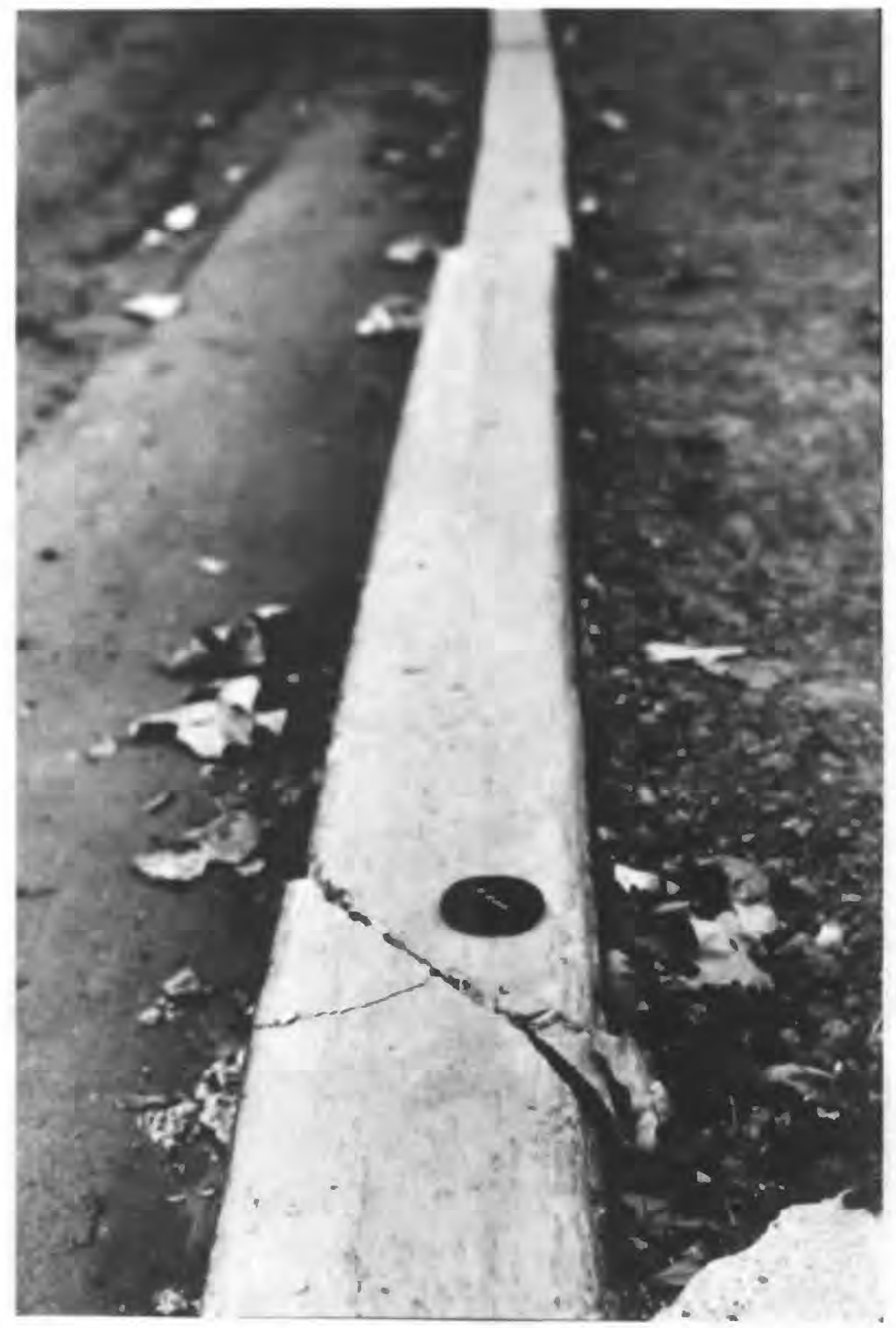

FIGURE 7. Free-standing concrete curb at north edge of 5th Street, between Powell and West Streets in Hollister, crossing creeping zone of Calaveras fault (view toward west). Diagonal break (foreground) is very recent as indicated by concrete rubble in gutter, and shows about $5 \mathrm{~mm}$ of right-lateral displacement. Transverse break (background) is older and shows $25-30 \mathrm{~mm}$ of displacement, but recent movement here also is indicated by cracks in soil to right (close-up views in Figs. $8 \mathrm{~A}$ and $8 \mathrm{~B})$. 


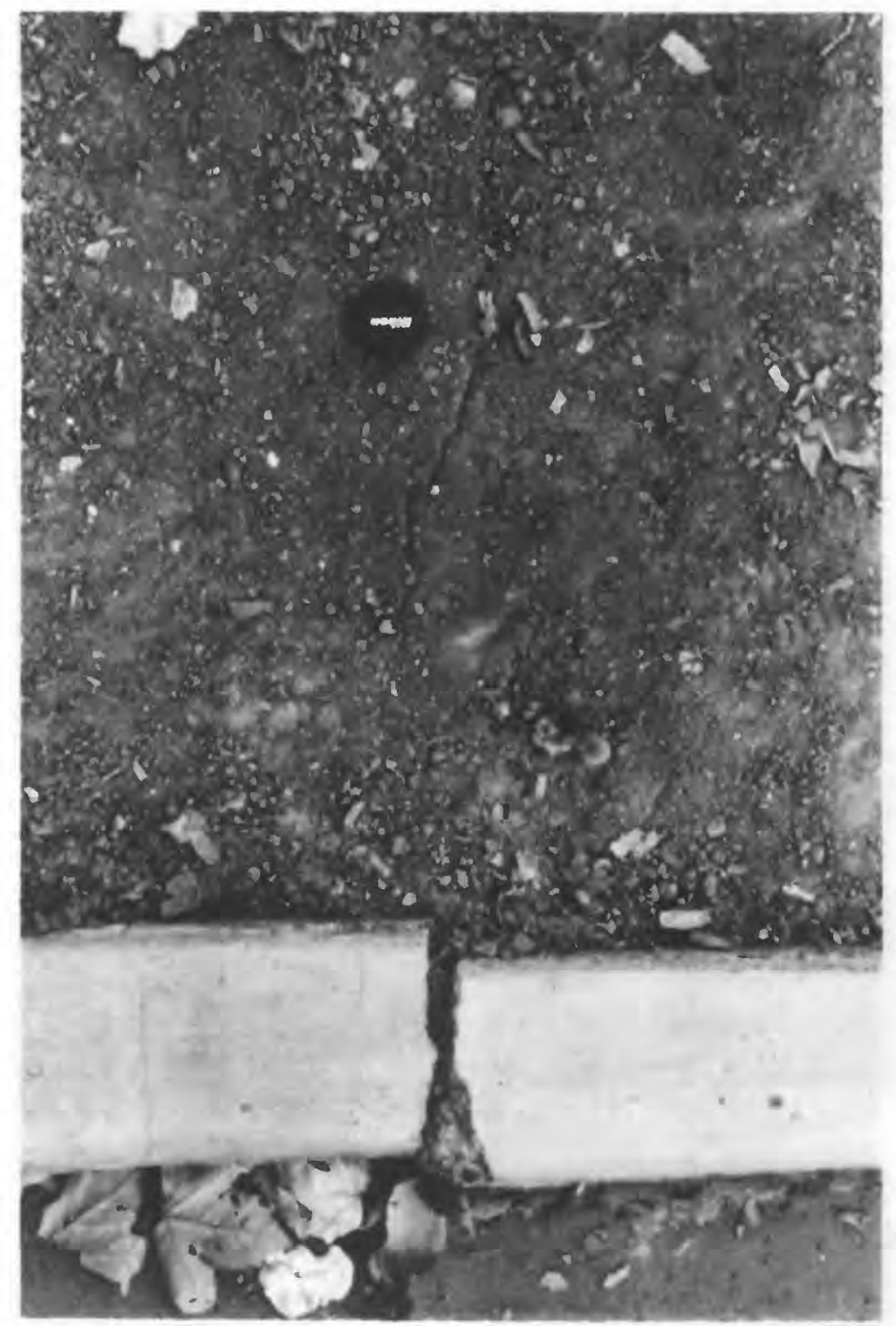

FIGURE 8A. Close-up view (from Fig. 7, background) of transverse break in concrete curb where active zone of the Calaveras fault crosses north edge of 5th Street, between Powell and West Streets in Hollister. Photograph taken at 13:00 on October 20, 1989. In the loose dry soil near lens cover note fresh crack parted by several $\mathrm{mm}$ possibly due to very recent fault slip (last significant rainfall was 21 days before photograph). 


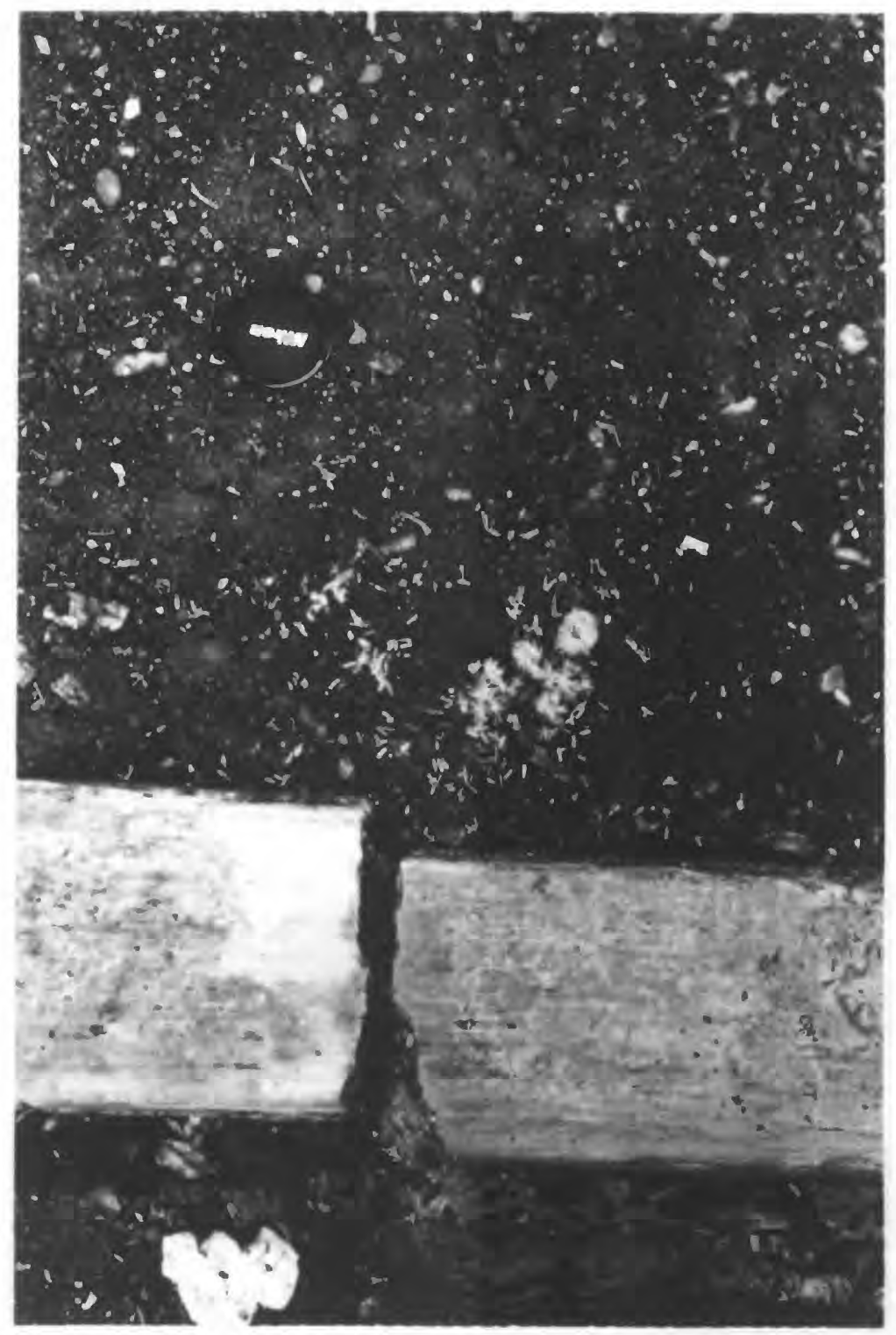

FIGURE 8B. Same curb and soil area as in Fig. 8A, at 13:00 on October 21, 1989, following a "trace" of rainfall (recorded at US National Weather Service Hollister station) within preceding 24 hours. The absence here of the soil crack photo-documented 24 hours earlier (in Fig. 8A) indicates ephemeral nature of these soil features. 


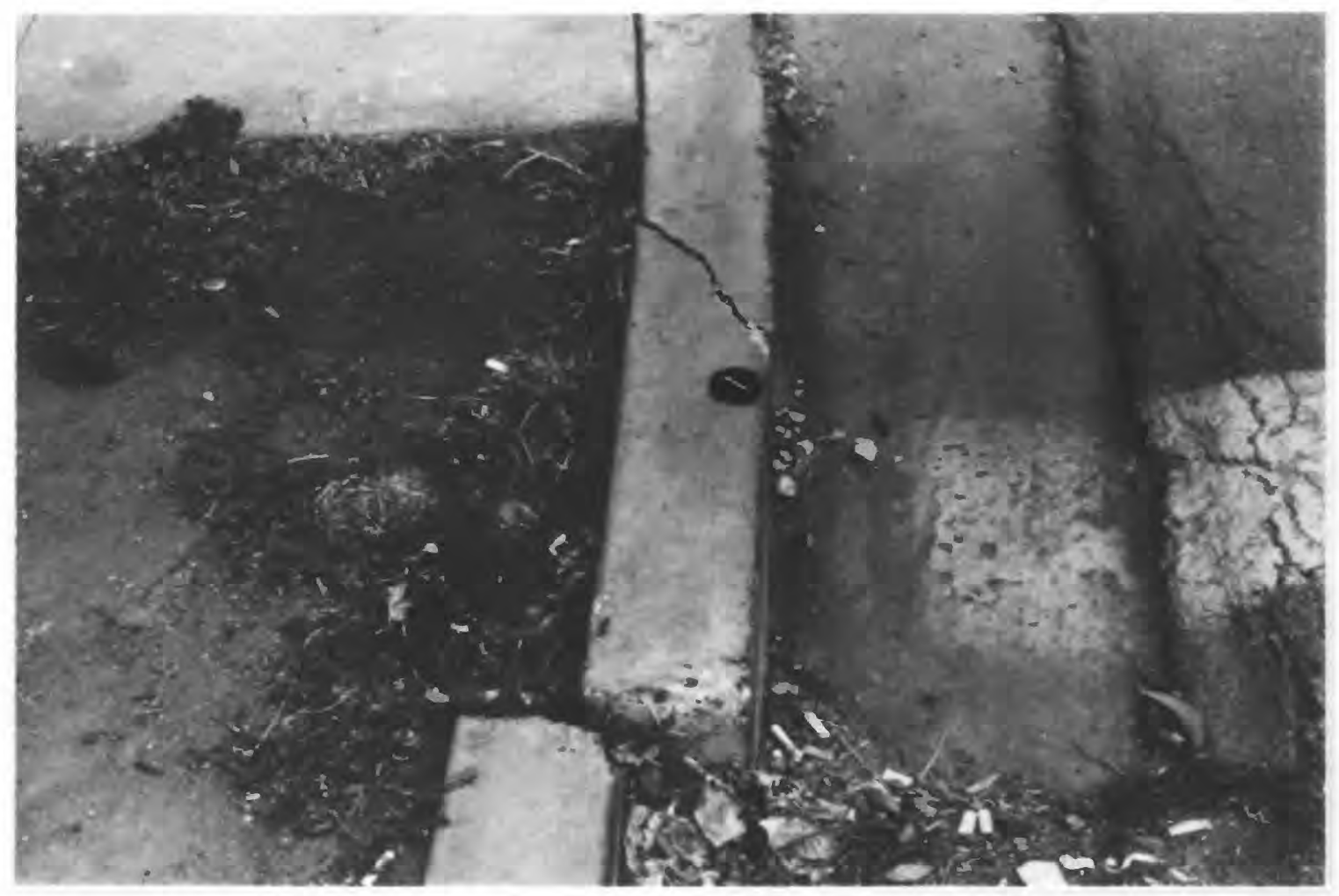

FIGURE 9. View toward west of south curb along South Street at Calaveras fault, between Powell and West Streets in Hollister. Note many years of accrued fault displacement between offset curb sections. Diagonal fracture, displaced right-laterally by about $5 \mathrm{~mm}$, is very recent (note rubble remaining in gutter) and probably related to Loma Prieta earthquake of October 17, 1989. 


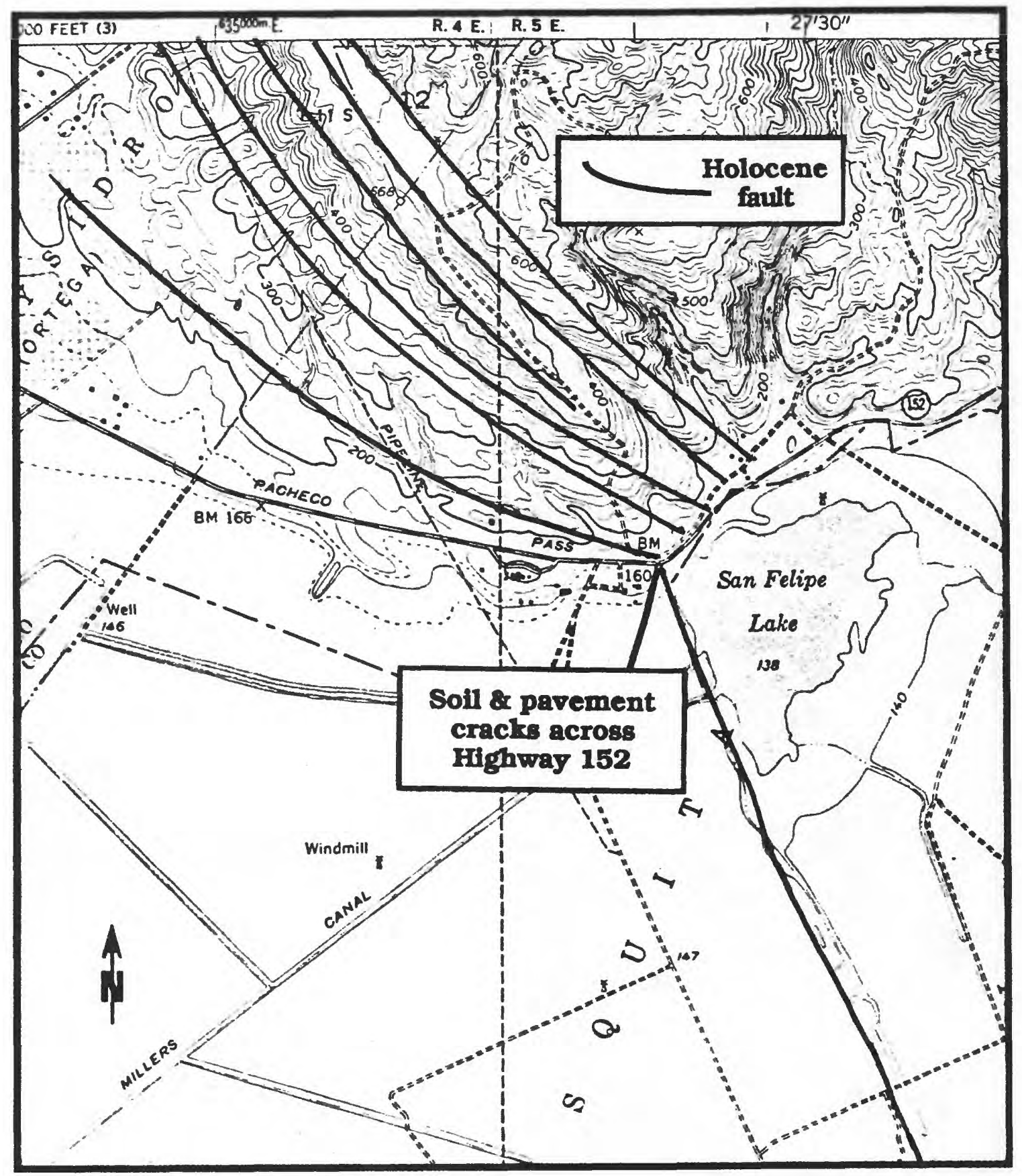

FIGURE 10. Map of vicinity of San Felipe Lake, $15 \mathrm{~km}$ northwest of Hollister, showing Holocene traces of the Calaveras fault zone (after Armstrong, and others, 1980), and site of right-lateral fault slip across Highway 152 apparently triggered by the Loma Prieta earthquake of October 17. 1989. (Base map is San Felipe 7.5-minute topographic quadrangle, USGS, scale 1:24,000.) 

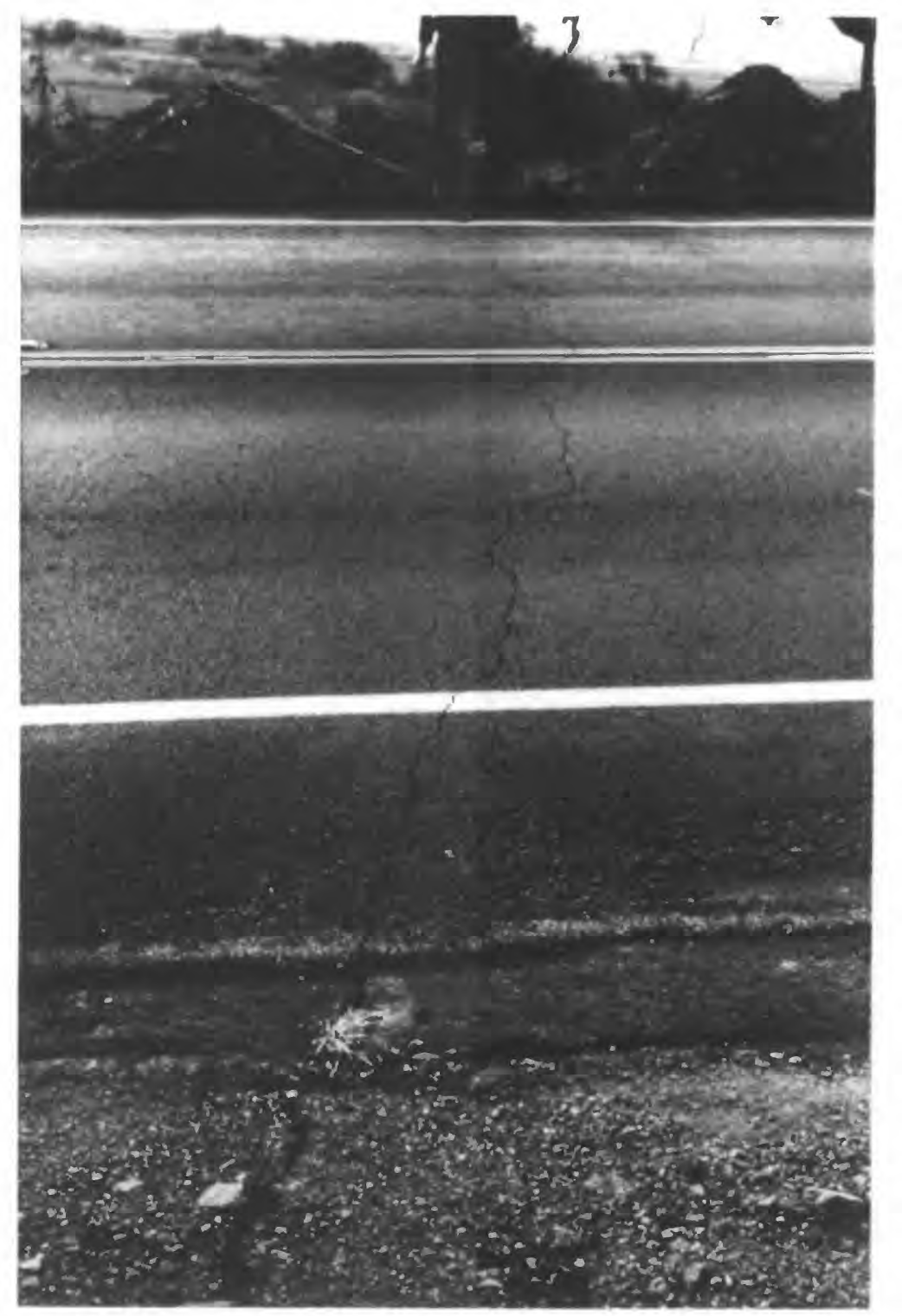

FIGURE 11. Single continuous crack through asphalt pavement of Highway 152 north of San Felipe Lake where recent slip occurred on an active trace of the Calaveras fault zone (view toward south). 


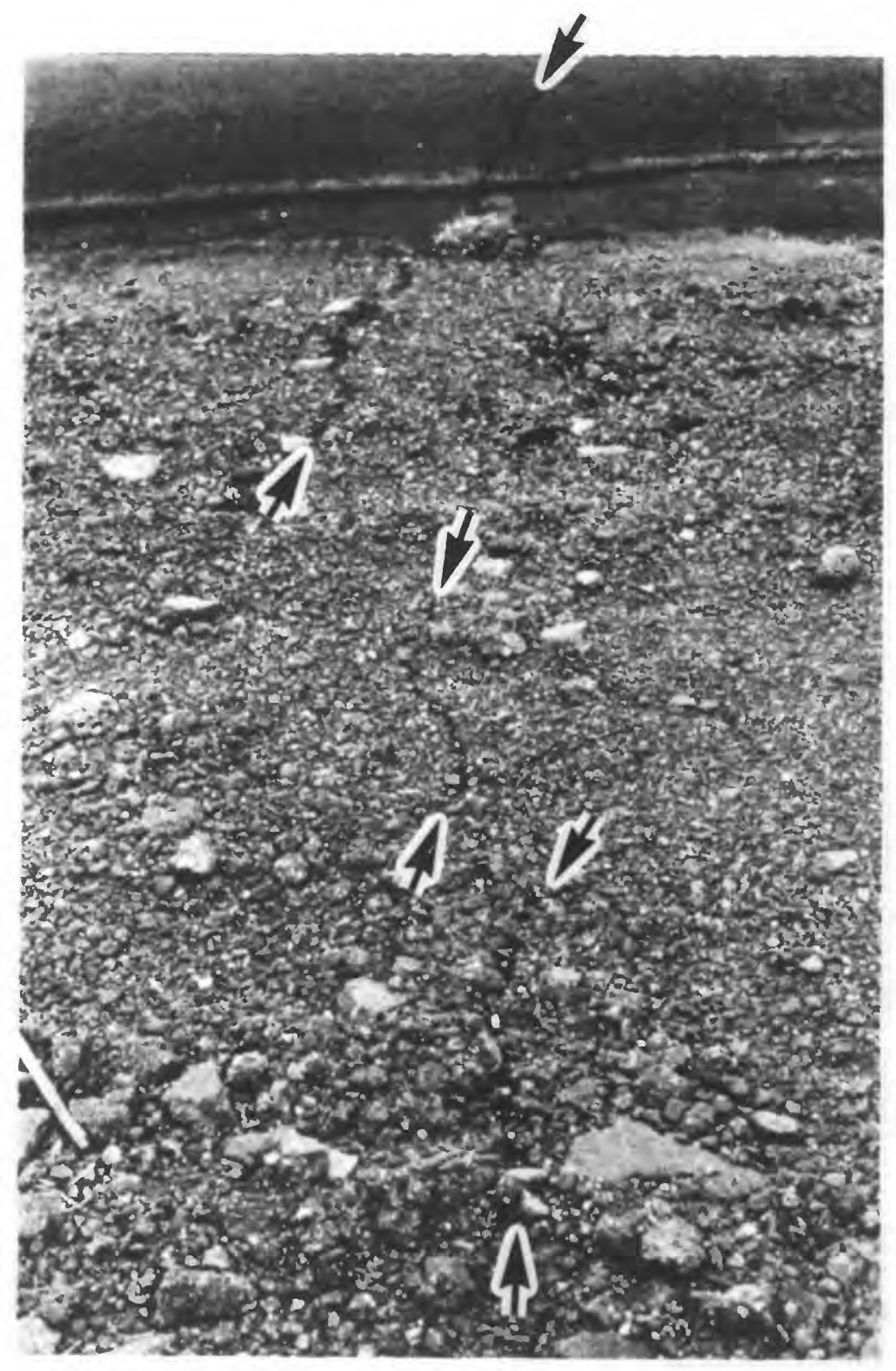

FIGURE 12. Recent en echelon cracks in gravel fill of roadbed at north side of Highway 152 north of San Felipe Lake (view toward south). Each crack is delimited by a pair of opposing arrows; en echelon zone is contiguous with asphalt crack across highway (Fig. 11). Photograph taken on October 21, 1989. 


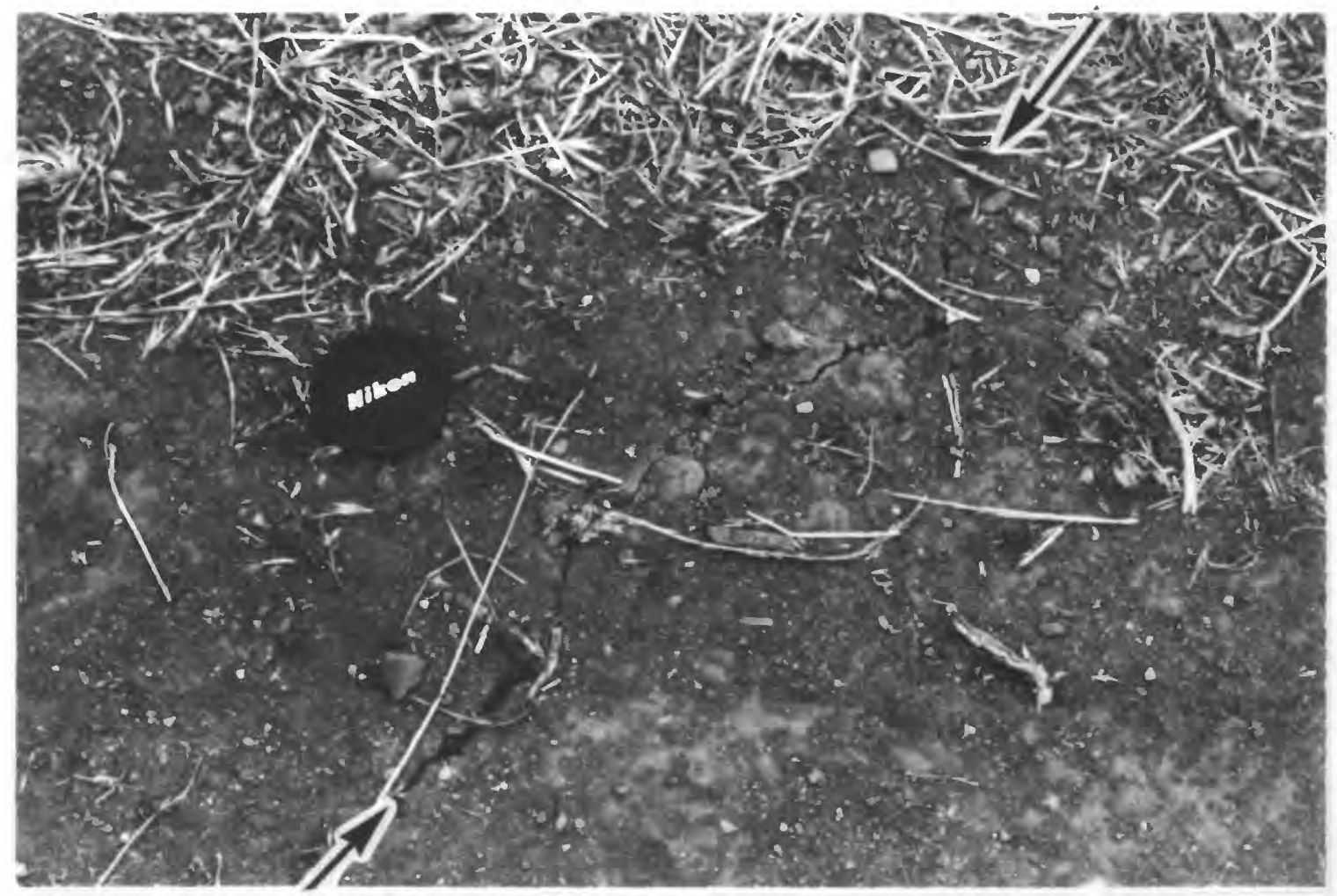

FIGURE 13. Fresh soil crack (between arrows) across tire track in dirt road 10 meters north of asphalt fracture in Highway 152 (Fig. 11) north of San Felipe Lake (north is toward lower left corner). Photograph taken on October 21, 1989. Note that crack is still evident in spite of a light rainfall within preceding 24 hours; this is probably attributed to the somewhat compacted condition of the soil beneath tire track and the insignificant rainfall amount $(0.01 \mathrm{inch}$ recorded at the US National Weather Service Gilroy station). 


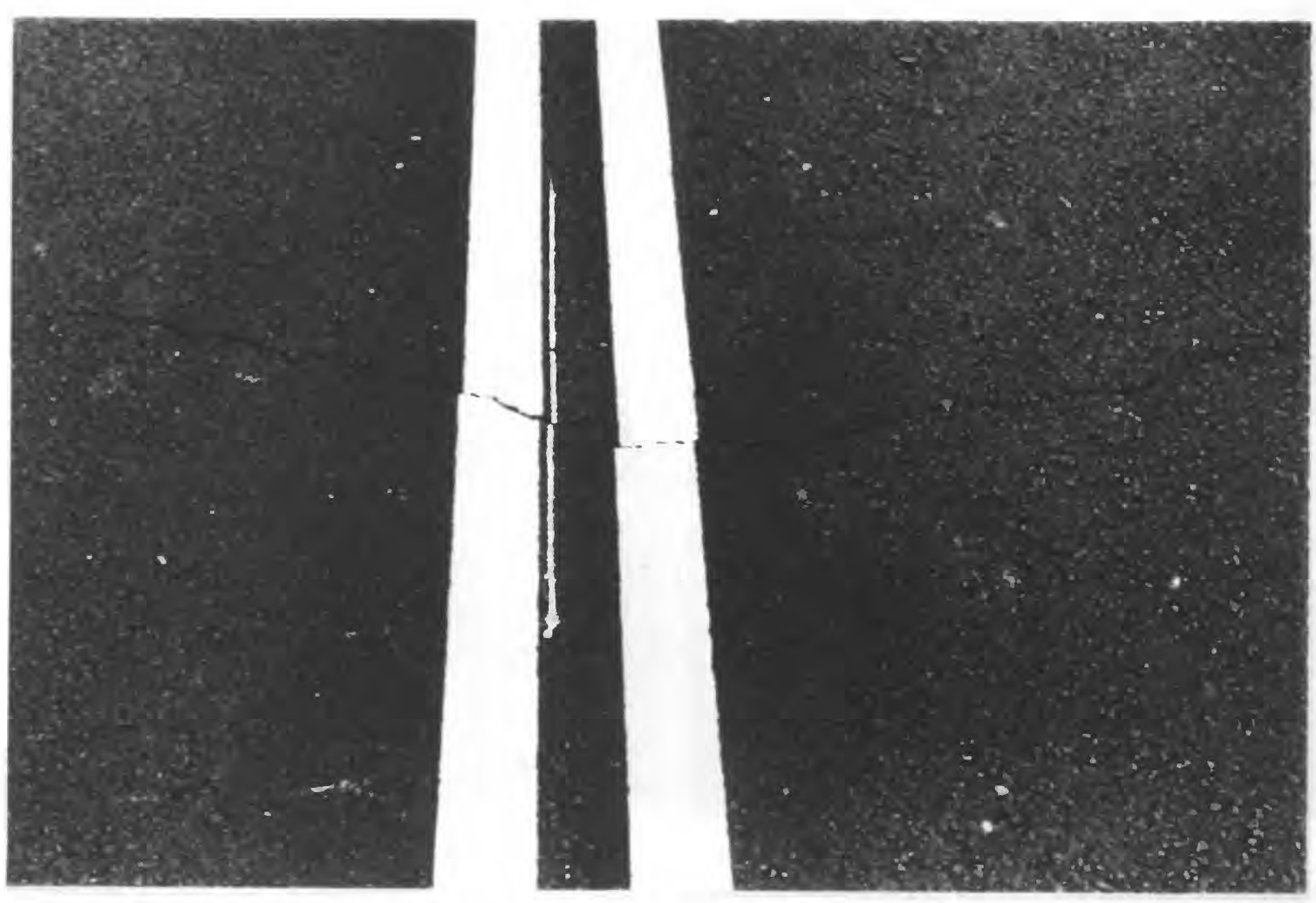

FIGURE 14. View toward east of median stripes of Highway 152 north of San Felipe Lake, clearly showing right-lateral displacement along a trace of Calaveras fault zone. Photograph was taken on October 21, 1989. 


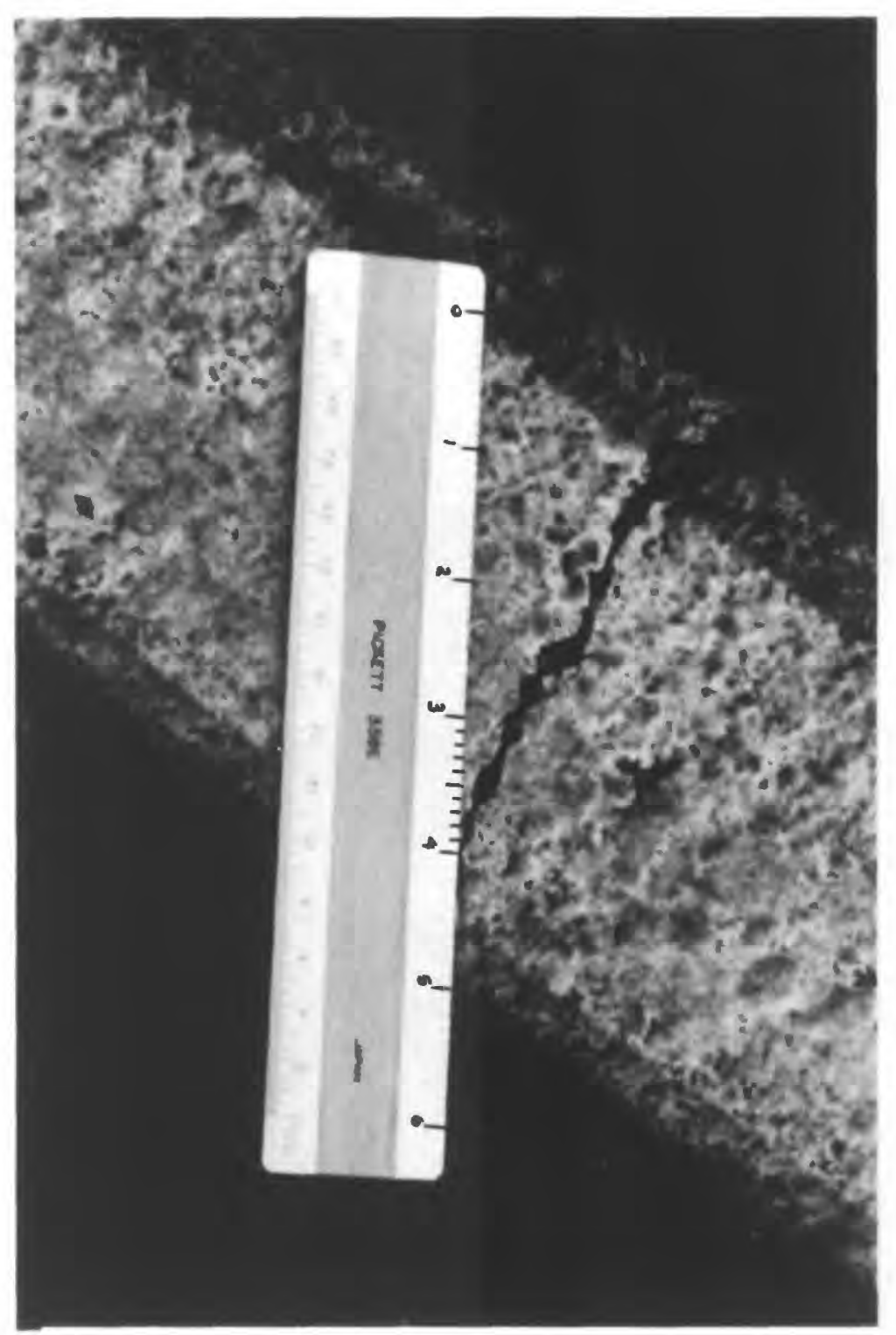

FIGURE 15. South border line of Highway 152 north of San Felipe Lake (north is toward upper right corner of photograph). Note tension cracks which show 0.2 inches $(5 \mathrm{~mm})$ of right-lateral displacement and a shear direction of N61W. Photograph was taken on October 21, 1989. Scale (retouched for clarity) is in inches. 

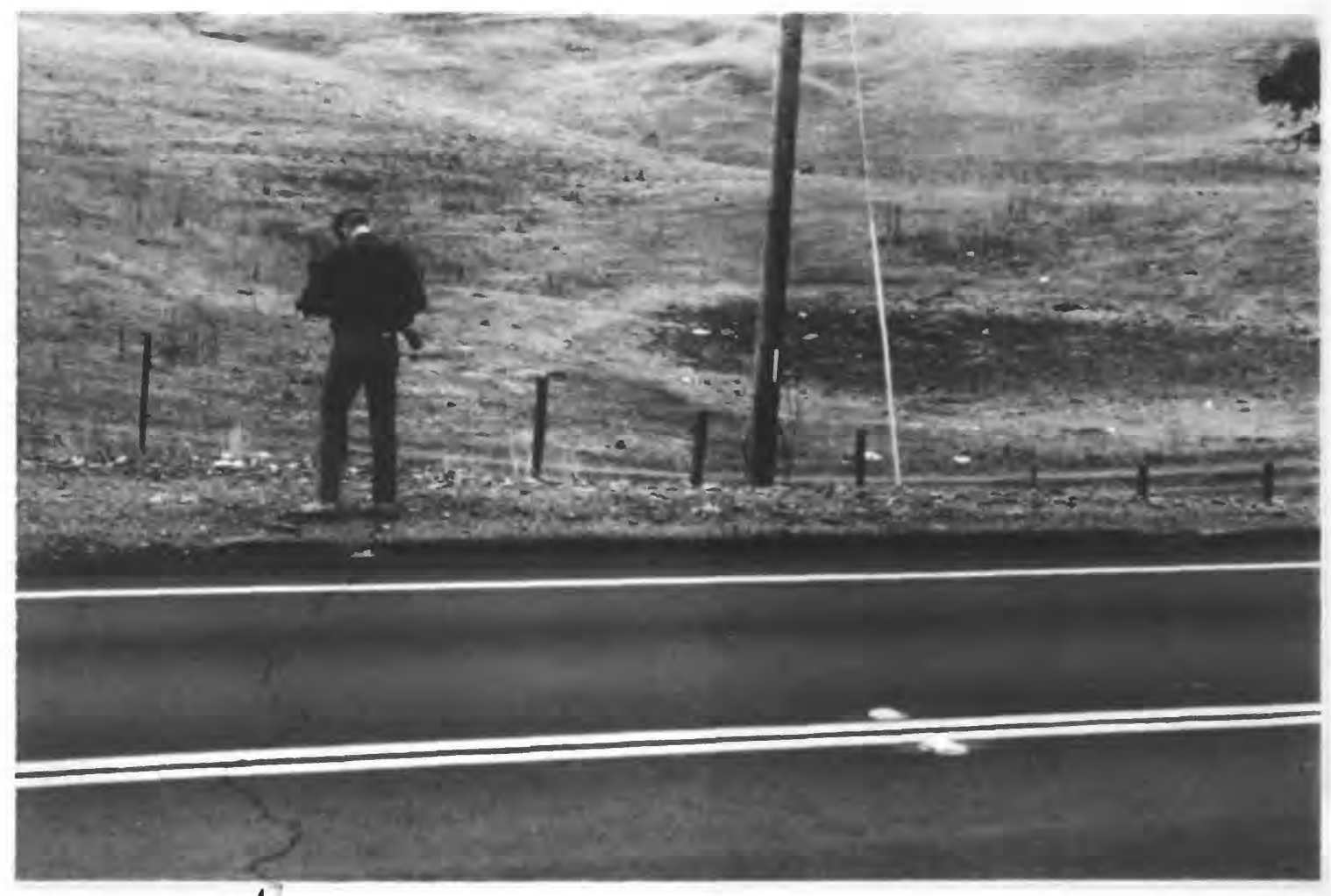

\section{4}

FIGURE 16. Sag pond (in right-center of view) within Calaveras fault zone on north side of Highway 152 north of San Felipe Lake. This closed depression is bounded on west by shear zone (expressed as the asphalt fracture between arrow and observer's right foot), documented in Figs. 11 through 15, and on east by another zone of shears that cut into north lane of highway. 


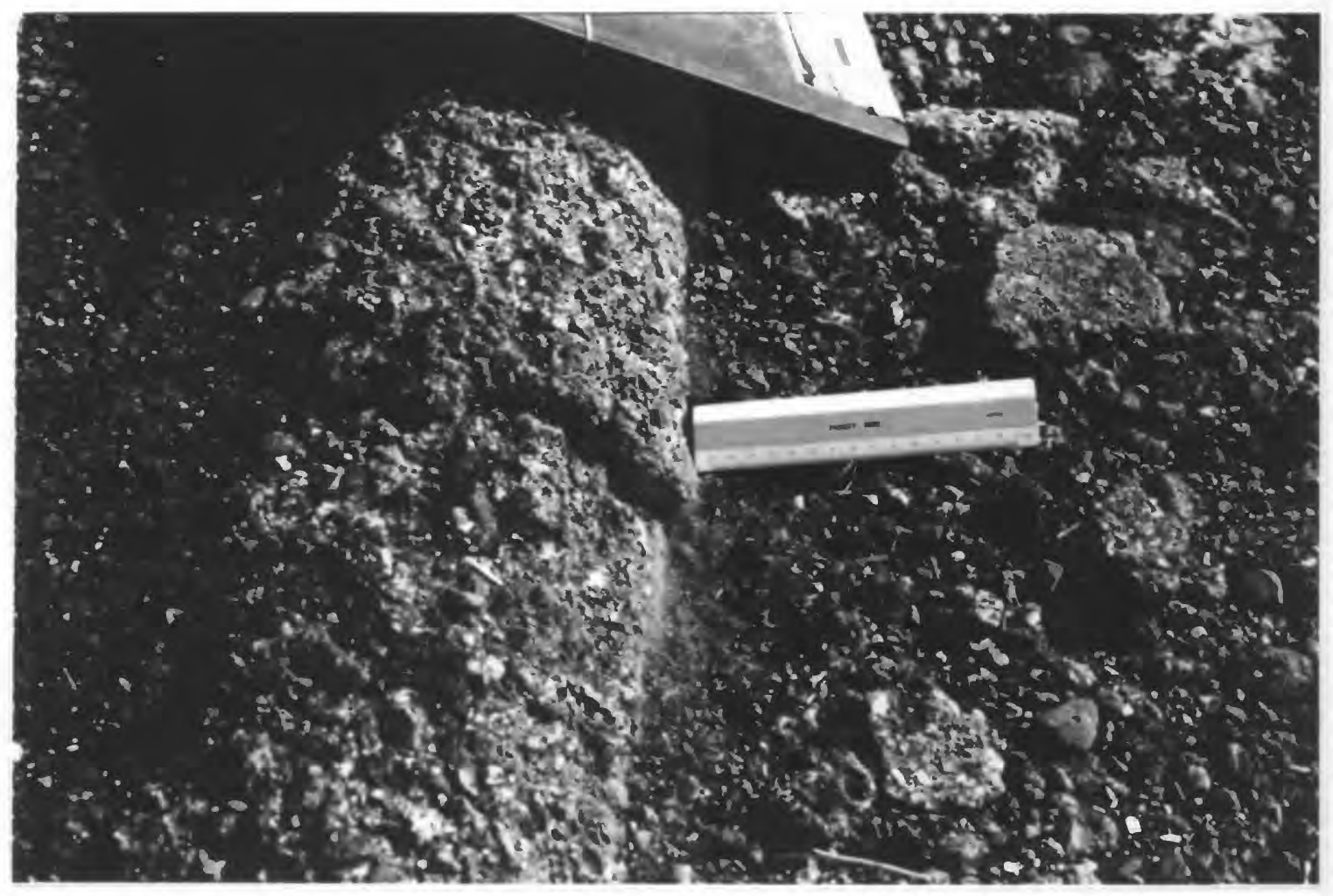

FIGURE 17. View toward east of recent asphalt pavement of road surface (far left) against older asphalt berm (center) along south side of Highway 152 north of San Felipe Lake, at south end of highway rupture in Fig. 11. Note that older berm is displaced right-laterally approximately 0.6 inches $(15 \mathrm{~mm})$ compared to $5 \mathrm{~mm}$ offset of recent asphalt pavement. 


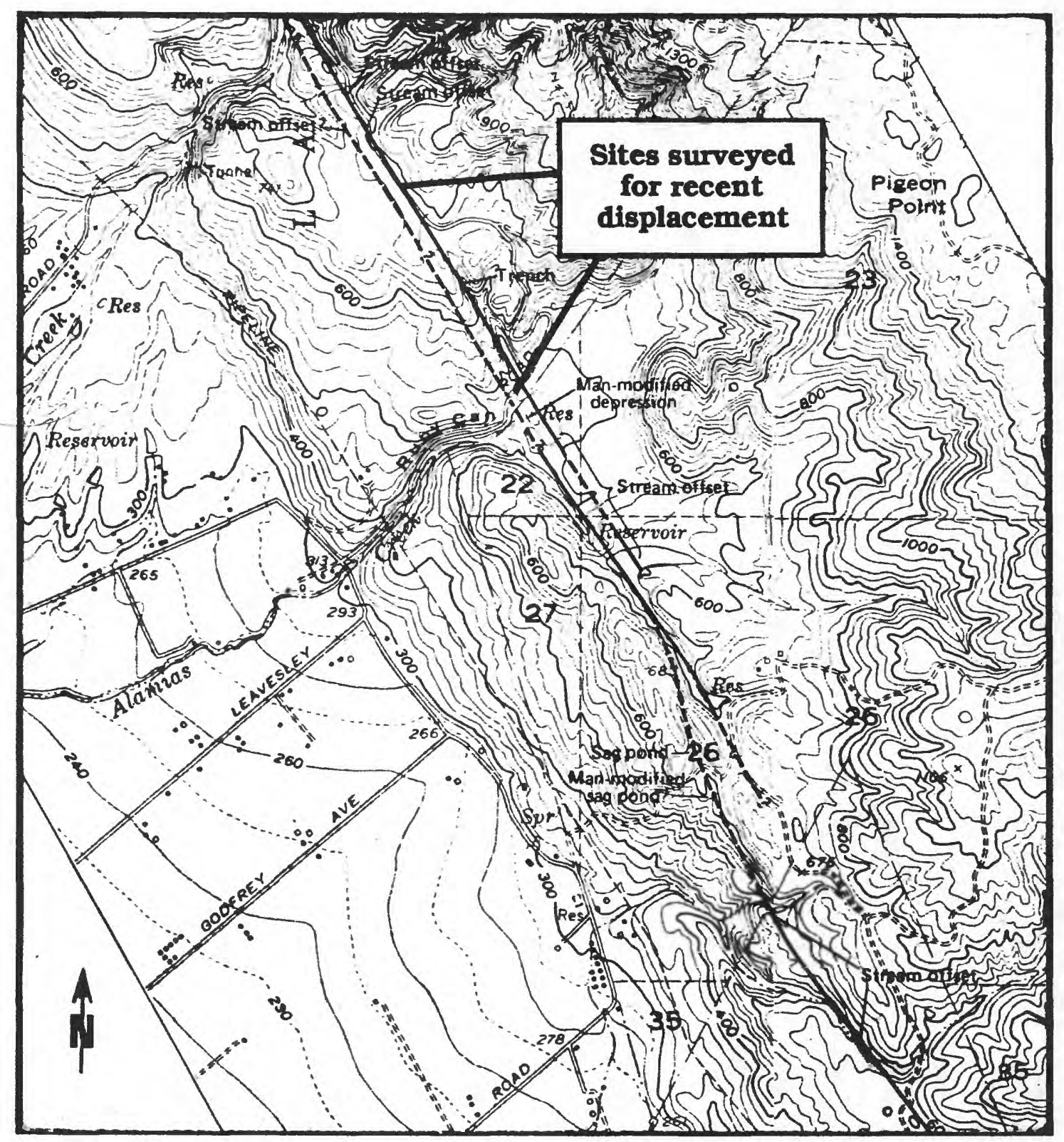

FIGURE 18. Location map of Ruby Canyon vicinity southeast of Coyote Reservoir (8.5 km northwest of San Felipe Lake) showing sites along the Calaveras fault zone we investigated for evidence of recent fault slip. (from Radbruch-Hall, 1974; base map is Gilroy 7.5-minute topographic quadrangle, USGS, scale $1: 24,000$.) 
OCTOBER 17-20 $1989 \quad M>2.0$

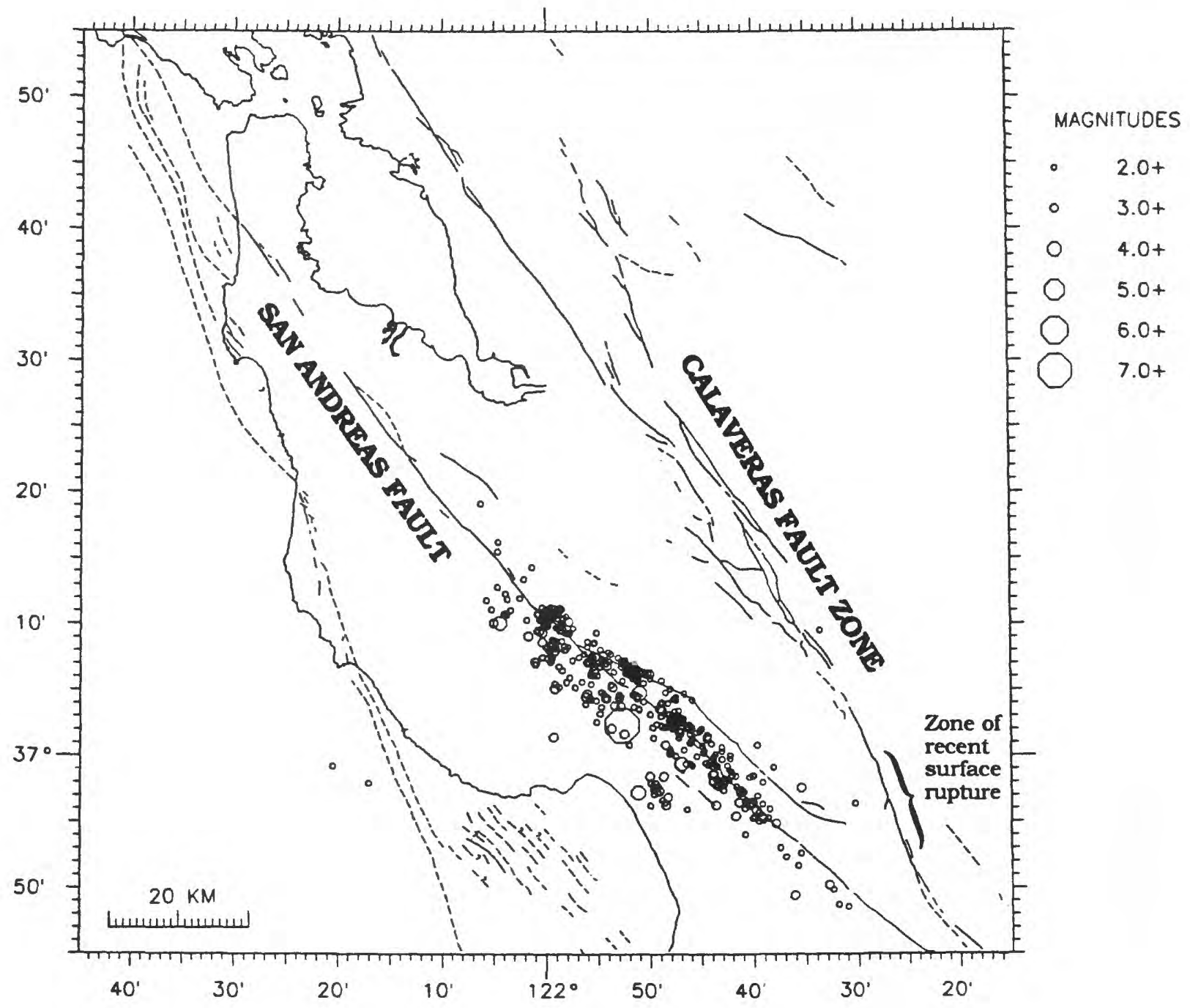

FIGURE 19. Seismicity map of the southern San Francisco Bay region showing M 2 and larger earthquakes from October 17 through October 20, 1989. 


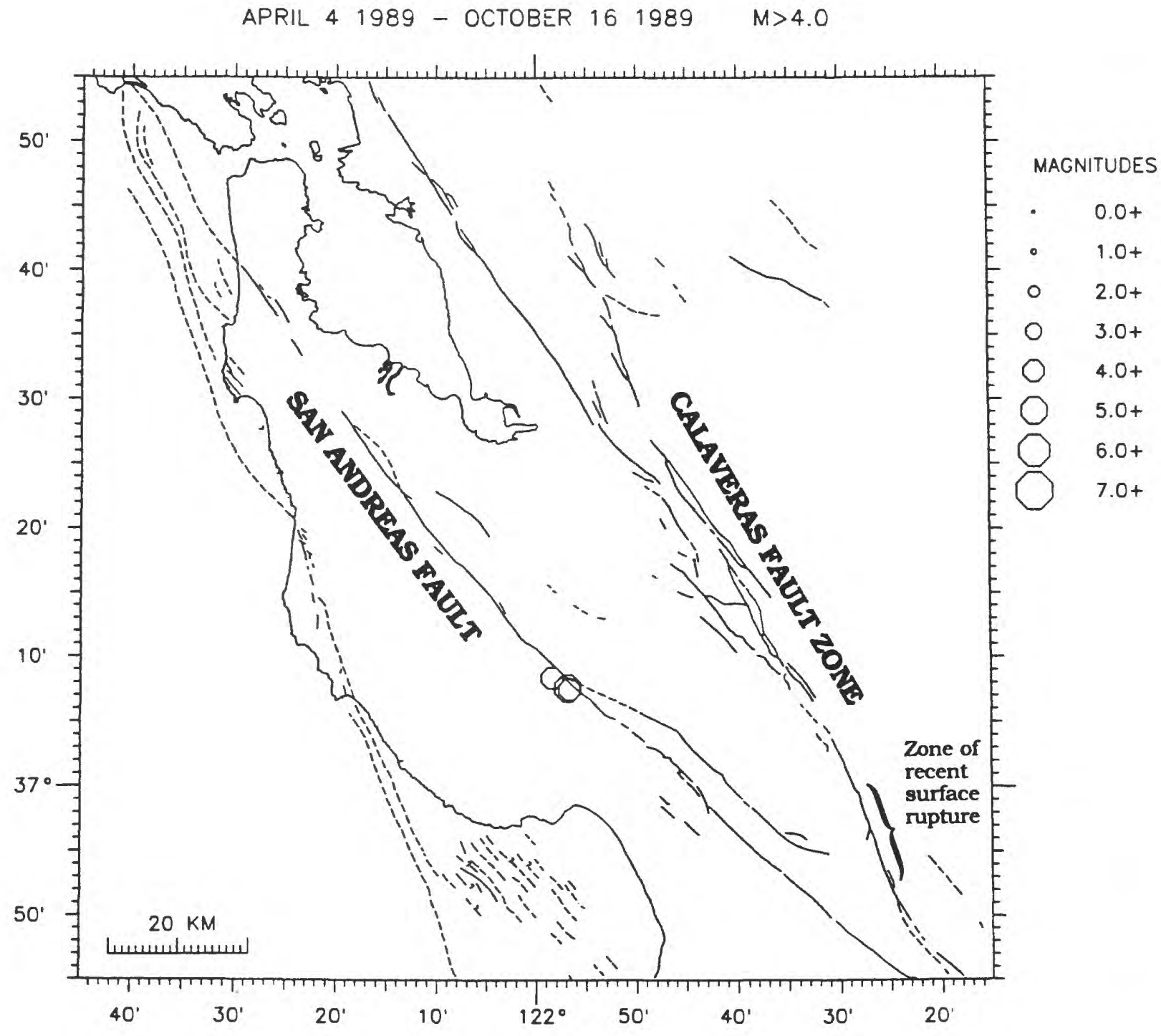

FIGURE 20. Seismicity map of the southern San Francisco Bay region showing M 4 and larger earthquakes during the 6 months prior to the Loma Prieta earthquake. 